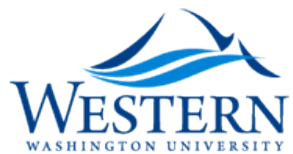

Western Washington University

Western CEDAR

$10-1996$

\title{
Late Cenozoic Structure and Tectonics of the Northern Mojave Desert
}

Elizabeth R. Schermer

liz.schermer@wwu.edu

B. P. Luyendyk

S. Cisowski

Follow this and additional works at: https://cedar.wwu.edu/geology_facpubs

Part of the Earth Sciences Commons

\section{Recommended Citation}

Schermer, Elizabeth R.; Luyendyk, B. P.; and Cisowski, S., "Late Cenozoic Structure and Tectonics of the Northern Mojave Desert" (1996). Geology Faculty Publications. 8.

https://cedar.wwu.edu/geology_facpubs/8

This Article is brought to you for free and open access by the Geology at Western CEDAR. It has been accepted for inclusion in Geology Faculty Publications by an authorized administrator of Western CEDAR. For more information, please contact westerncedar@wwu.edu. 


\title{
Late Cenozoic structure and tectonics of the northern Mojave Desert
}

\author{
E.R. Schermer \\ Geology Department, Western Washington University, Bellingham \\ B.P. Luyendyk and S. Cisowski \\ Institute for Crustal Studies and Department of Geological Sciences, University of California, Santa Barbara
}

\begin{abstract}
In the Fort Irwin region of the northern Mojave desert, late Cenozoic east striking sinistral faults predominate over northwest striking dextral faults of the same age. Kinematic indicators and offset marker units indicate dominantly sinistral strike slip on the east striking portions of the faults and sinistralthrust slip on northwest striking, moderately dipping segments at the east ends of the blocks. Crustal blocks $\sim 7-10 \mathrm{~km}$ wide by $\sim 50 \mathrm{~km}$ long are bounded by complex fault zones up to $2 \mathrm{~km}$ wide at the edges and ends of each block. Faulting initiated after $\sim 11 \mathrm{Ma}$, and Quaternary deposits are faulted and folded. We document a minimum of $13 \mathrm{~km}$ cumulative sinistral offset in a north-south transect from south of the Bicycle Lake fault to north of the Drinkwater Lake fault. Paleomagnetic results from 50 sites reveal two direction groups in early and middle Miocene rocks. The north-to-northwest declinations of the first group are close to the middle Miocene reference pole. However, rock magnetic studies suggest that both primary and remagnetized directions are present in this group. The northeast declinations of the second group are interpreted as primary and $63.5^{\circ} \pm 7.6^{\circ}$ clockwise from the reference pole and suggest net post middle Miocene clockwise rotation of several of the east trending blocks in the northeast Mojave domain. The Jurassic Independence Dike Swarm in Fort Irwin may be rotated $25-80^{\circ}$ clockwise relative to the swarm north of the Garlock fault, thus supporting the inference of clockwise rotation. Using a simple-shear model that combines sinistral slip and clockwise rotation of elongate crustal blocks, we predict $\sim 23^{\circ}$ clockwise rotation using the observed fault slip, or one-third that inferred from the paleomagnetic results. The discrepancy between slip and rotation may reflect clockwise bending at the ends of fault blocks, where most of our paleomagnetic sites are located. However, at least $25^{\circ}-40^{\circ}$ of clockwise tectonic rotation is consistent with the observed slip on faults within the domain plus possible "rigidbody" rotation of the region evidenced by clockwise bending of northwest striking domain-bounding faults. Our estimates of sinistral shear and clockwise rotation suggest that approximately half of the $65 \mathrm{~km}$ of dextral shear in the Eastern California Shear Zone over the last $10 \mathrm{~m}$.y. occurred within the northeast Mojave Domain. The remainder must be accommodated in adjacent structural domains, e.g., east of the Avawatz Mountains and west of the Goldstone Lake fault.
\end{abstract}

Copyright 1996 by the American Geophysical Union.

Paper number 96TC00131. 0278-7407/96/96TC-00131\$12.00

\section{Introduction}

The Cenozoic tectonic history of the Mojave Desert block (Figure 1) has been the subject of much recent study, in part because of its relation to the San Andreas fault system and southern California seismicity. Deformation in the Mojave Desert provides a link between the San Andreas system, the Garlock fault, and the Southern Death Valley fault zone, and transfers plate margin deformation to the Basin and Range Province [Atwater, 1970, 1989; Dokka and Travis, 1990b]. Dokka and Travis [1990a,b] named this apparently interrelated region of dextral shear from the San Andreas fault to the Southern Death Valley Fault zone the Eastern California Shear Zone and argued that it accounts for $\sim 15 \%$ of the total shear along the Pacific-North America plate boundary. Quantitative data on deformation across the entire width of the plate boundary zone provide constraints on the mechanics and dynamics of transform margin processes; thus it is critical to determine the kinematics of deformation in the Mojave block as a whole. Geodetic studies indicate $8-10 \mathrm{~mm} / \mathrm{yr}$ of right-lateral shear resolved on northwest striking faults [Sauber et al., 1986, 1994; Savage et al., 1990] compared with $\sim 35 \mathrm{~mm} / \mathrm{yr}$ on the San Andreas fault, and geologic and plate tectonic studies suggest that faults of the Mojave block have been accommodating a portion of the relative plate motion for at least the last $\sim 10 \mathrm{~m}$.y. [Dokka and Travis, 1990a].

Questions and controversy exist regarding the amount, timing, and distribution of strain on faults and folds in the Mojave block and regarding the importance and distribution of vertical-axis rotations of fault blocks [e.g., Garfunkel, 1974; Luyendyk et al., 1980; Bartley et al., 1990; Dokka and Travis, 1990a; Luyendyk, 1991]. In the northern Mojave Desert region bounded by the Garlock fault, the Avawatz Mountains, the Goldstone Lake fault, and the Cady fault (Figure 1; herein called the Northeast Mojave Domain) the major faults appear on published maps [Jennings et al., 1962; Jennings, 1992] as east striking as opposed to northwest striking as they are elsewhere in the Mojave block. The geometric similarity of the Northeast Mojave Domain to the Transverse Ranges has led to predictions of left slip and either little rotation [Garfunkel, 1974] or clockwise rotation [Luyendyk et al., 1980; Carter et al., 1987] of elongate fault blocks of the Northeast Mojave Domain in conjunction with right slip and minor counterclockwise rotation of blocks bounded by northwest striking faults. In contrast, Dokka and Travis [1990a] and Dokka [1992] proposed that deformation in the Northeast Mojave Domain occurred mainly by large amounts of right slip on north- 


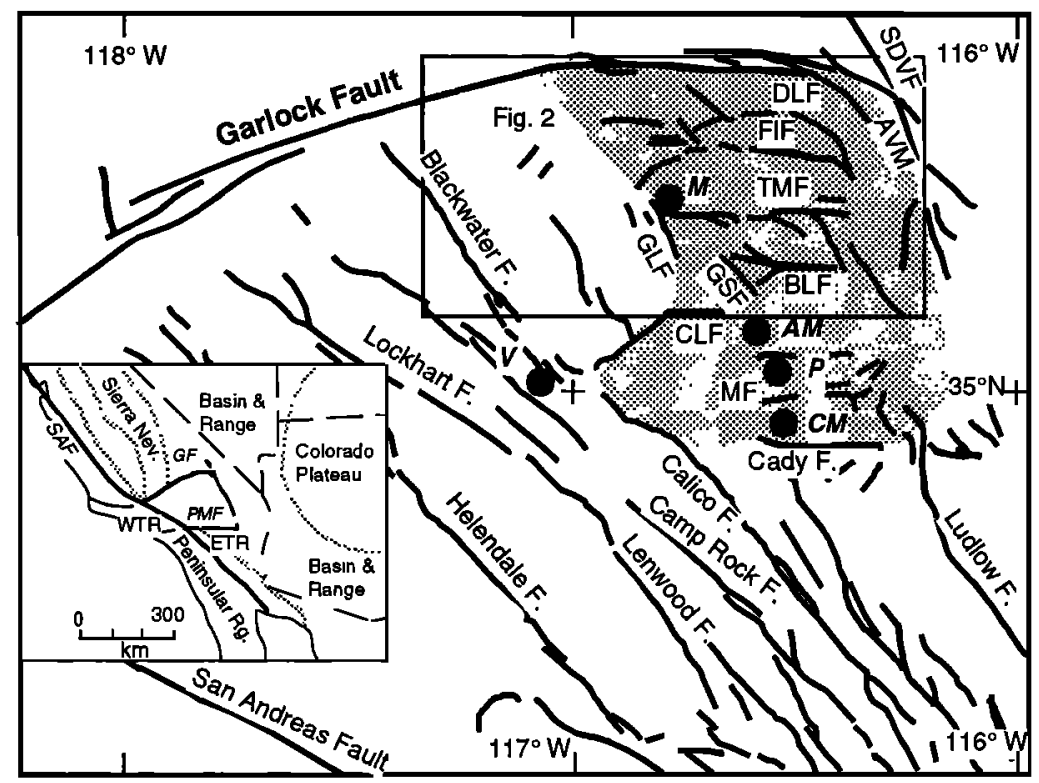

Figure 1. Generalized fault map of Mojave Desert [after Jennings, 1992]. Box outlines map in Figure 2; shaded area indicates Northeast Mojave Domain as described in text. Abbreviations are AVM, Avawatz Mountains; BLF, Bicycle Lake fault; CLF, Coyote Lake fault; CM, Cady Mountains; DLF, Drinkwater Lake fault; FIF, Fort Irwin fault; GLF, Goldstone Lake fault; GSF, Garlic Spring fault; MF, Manix fault; SDVF, Southern Death Valley fault; TMF, Tiefort Mountain fault. Paleomagnetic studies are indicated by the large dots: M, MacConnell et al. [1994]; V, Valentine et al. [1993]; AM, Alvord Mountains studies of Ross et al. [1989] and R.E.Wells and J.W. Hillhouse (personal communication 1994); P, Pluhar et al. [1991]; CM, Cady Mountains study of MacFadden et al. [1990]. Inset is regional map of the Mojave Desert and adjacent tectonic provinces. GF, Garlock fault; SAF, San Andreas fault, PMF, Pinto Mountain Fault; ETR, WTR, Eastern and Western Transverse Ranges, respectively.

west striking faults with minor left slip and little rotation on east striking faults. In this paper we describe geologic mapping and structural and paleomagnetic analysis in the Fort Irwin National Training Center (Figure 1). This study was designed to address the question of how the plate motion is partitioned within and across this part of the plate boundary zone, specifically to determine the geometry, kinematics, and timing of faulting and the role and distribution of vertical-axis rotations. We also consider the question of the relation between fault slip and rotation of blocks and the size, shape, and rigidity of crustal blocks, as well as implications of the data for models of the Mojave region.

\section{Geologic Background}

Geological and geophysical studies of the Mojave desert block have recognized three important types of Cenozoic deformation. During early Miocene time, the central Mojave region experienced large-scale, northeast directed extension [e.g., Dokka et al., 1988; Glazner et al., 1988; Dokka, 1989; Glazner et al., 1989; Walker et al., 1990], locally accompanied by clockwise rotation [Ross et al., 1989; Ross, 1995]. Later strike-slip faulting along northwest striking dextral faults apparently began during late Miocene time [Dibblee, 1961, 1967; Dokka, 1983; Dokka and Travis, 1990a]. In addition, north-south shortening has been recently recognized as playing an important role in the Miocene and younger deformation of the Mojave region [Bartley et al., 1990; Glazner and Bartley, 1994].
Previous work in the Fort Irwin region of the Northeast Mojave Domain consists of reconnaissance mapping for the Trona 1:250,000 sheet [Jennings et al., 1962], together with more detailed recent work related to the present study [Miller et al., 1994; Yount et al., 1994] and studies in areas bordering Fort Irwin [Byers, 1960; Brady, 1984a,b; Spencer, 1990a,b; MacConnell et al., 1994; Sabin et al., 1994]. Our new mapping and geochronology documents the following pre-Tertiary geologic history of the Fort Irwin region. The oldest rocks consist of Precambrian basement $(\sim 1.4 \mathrm{Ga})$ and probable Late Precambrian and Paleozoic miogeoclinal metasedimentary rocks that occur as screens in Jurassic and Cretaceous plutonic rocks. Plutonic and volcanic rocks were deformed in Middle Jurassic time, cut by the $148 \mathrm{Ma}$ Independence dike swarm, and deformed again at $\sim 105 \mathrm{Ma}$ [Stephens et al., 1993; Schermer et al., 1994; Stephens, 1994]. The Mesozoic events left a pervasive mylonitic foliation and lineation in pre-Late Cretaceous rocks in much of the Fort Irwin region. Deformed rocks were intruded by Late Cretaceous ( $\sim 80 \mathrm{Ma})$ granitoids [Miller and Sutter, 1982]. A period of uplift and erosion occurred following Late Cretaceous plutonism and prior to deposition and eruption of Miocene sedimentary and volcanic rocks.

Tertiary volcanic rocks in Fort Irwin and surrounding regions range in age from $\sim 21 \mathrm{Ma}$ to $5 \mathrm{Ma}$ and consist of silicic to mafic volcanic rocks, including several vent complexes [Spencer, 1990b; Sabin et al., 1993, 1994; Keith et al., 1994; Sabin et al., 1994; Schermer, 1994]. Most of the units dip gently and range in 


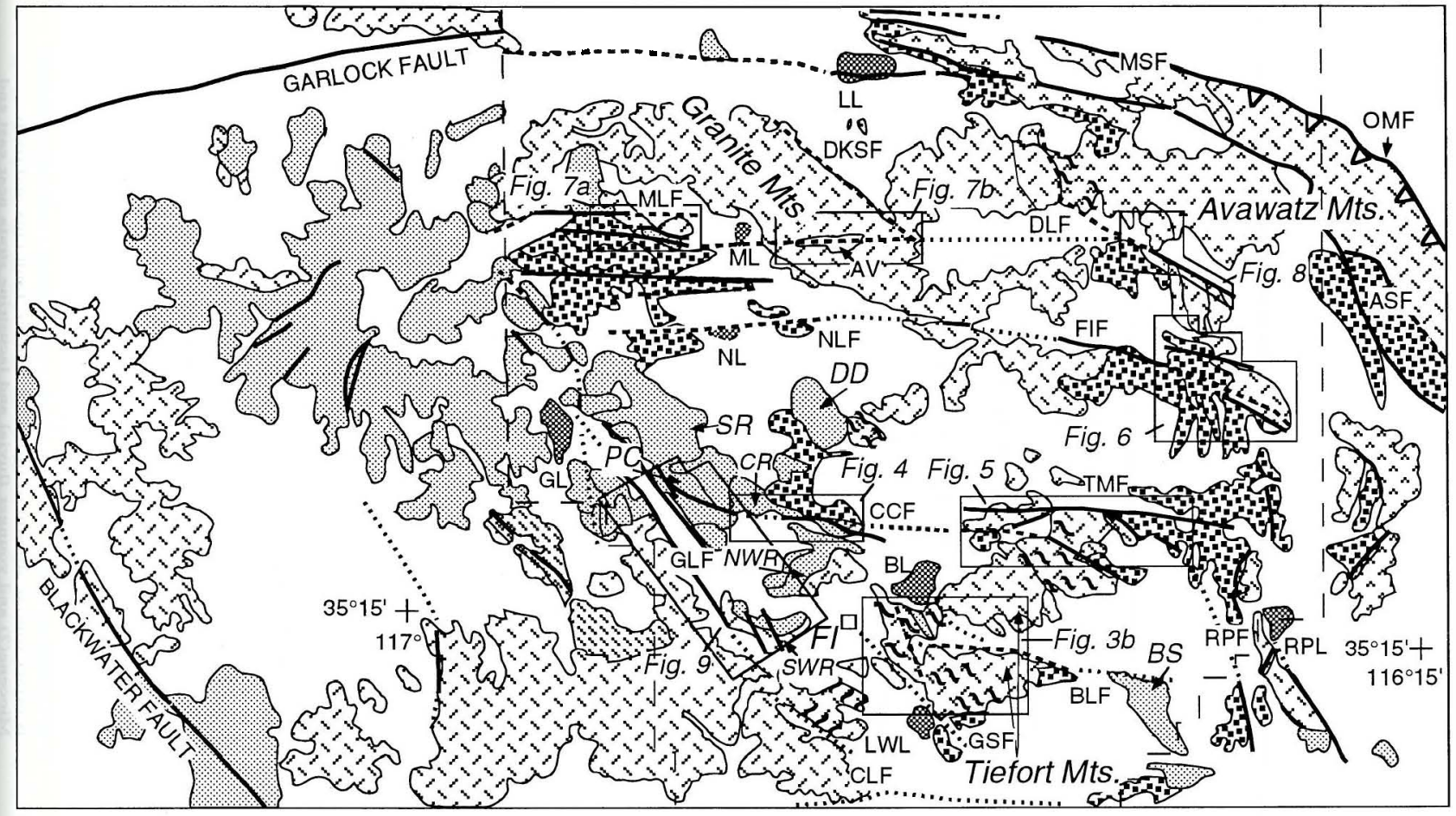
$20 \mathrm{~km}$

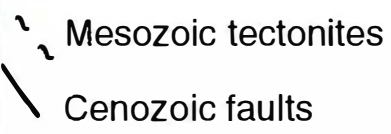

10 Quaternary dry lakes

\section{Quaternary and Tertiary} volcanic rocks

B. Early Quaternary, Tertiary sedimentary rocks
(2) Jurassic, Cretaceous plutonic rocks

An Mesozoic metavolcanic rocks

pre-Mesozoic metamorphic rocks

Figure 2. Generalized geologic map of the Fort Irwin region, modified from Jennings et al., [1962] and Spencer, [1990a]. Fort Irwin National Training Center isoutlined by dashed box; China Lake Naval Weapons Center is area west of Fort Irwin. Abbreviations not defined in Figure 1 are AV, Alpine Valley; ASF, Arrastre Spring fault; BL, Bicycle Lake; BS, Bitter Spring; CCF, Coyote Canyon fault; CR, Coyote Ridge; DD, Dacite Dome; DKSF, Desert King Spring fault; FI, Fort Irwin town; GL, Goldstone Lake; GSF, Garlic Spring fault; LL, Leach Lake; LWL, Langford Well lake; ML, McLean Lake; MLF, McLean Lake fault; MSF, Mule Spring branch of Garlock fault NL, Nelson Lake; NLF, Nelson Lake fault; NWR, Northwest Ridge; OMF, Old Mormon Spring fault; PC, Pink Canyon; RPF, Red Pass fault; RPL, Red Pass lake; SR, Stone Ridge; SWR, Southwest Ridge. Locations of Figures 3b-9 are outlined by boxes.

age from 19 to 16 Ma [Sabin et al., 1994; Schermer, 1994]; however, locally younger $(\sim 12 \mathrm{Ma})$ rocks occur at China Lake to the west [Sabin et al., 1994] and Alvord Mountain to the south (A.F. Glazner, written communication, 1995) (Figures 1 and 2). The typical Tertiary sequence consists of thin silicic tuff and tuff breccia overlying basement, followed by thick rhyolite lavas then basalt. The thicknesses of units are highly variable owing to erosional paleotopography on the pre-Tertiary basement and paleotopography created by silicic flows and domes. Mafic (basalt and basaltic andesite) and silicic (rhyolite and dacite) magmatism are coeval; however, basalts predominate at the top of the section [Keith et al., 1994; Schermer, 1994]. Volcanism largely ceased in this region by $\sim 12 \mathrm{Ma}$ [Sabin et al., 1994]; however, small-volume basalt lavas of latest Miocene age (5.6 Ma [Schermer, 1994]) and silicic air fall tuffs of Pliocene age ( 3.5 Ma (D. M. Miller written communication, 1995)) occur locally intercalated within sedimentary sequences that lie unconformably above older rocks.

Miocene sedimentary rocks are sparse and dominantly crop out in eastern Fort Irwin and the Avawatz Mountains (Figure 2) where Spencer [1990a, b] documented early to middle Miocene extension along high-angle normal faults along with basin formation and filling. Tertiary deposits in Fort Irwin include gently to moderately dipping medial to distal alluvial fan and fluvial deposits of middle Miocene age and alluvial and playa deposits of Pliocene to Quaternary age, with local intercalations of silicic air fall tuff [Sobieraj, 1994; Sobieraj and Schermer, 1994; Yount et al., 1994].

The presence of subhorizontal bedding (except where locally affected by strike-slip faults) and the relative abundance of volcanic rocks and sparseness of sedimentary rocks suggest that little extension occurred in most of the study area. This is in 


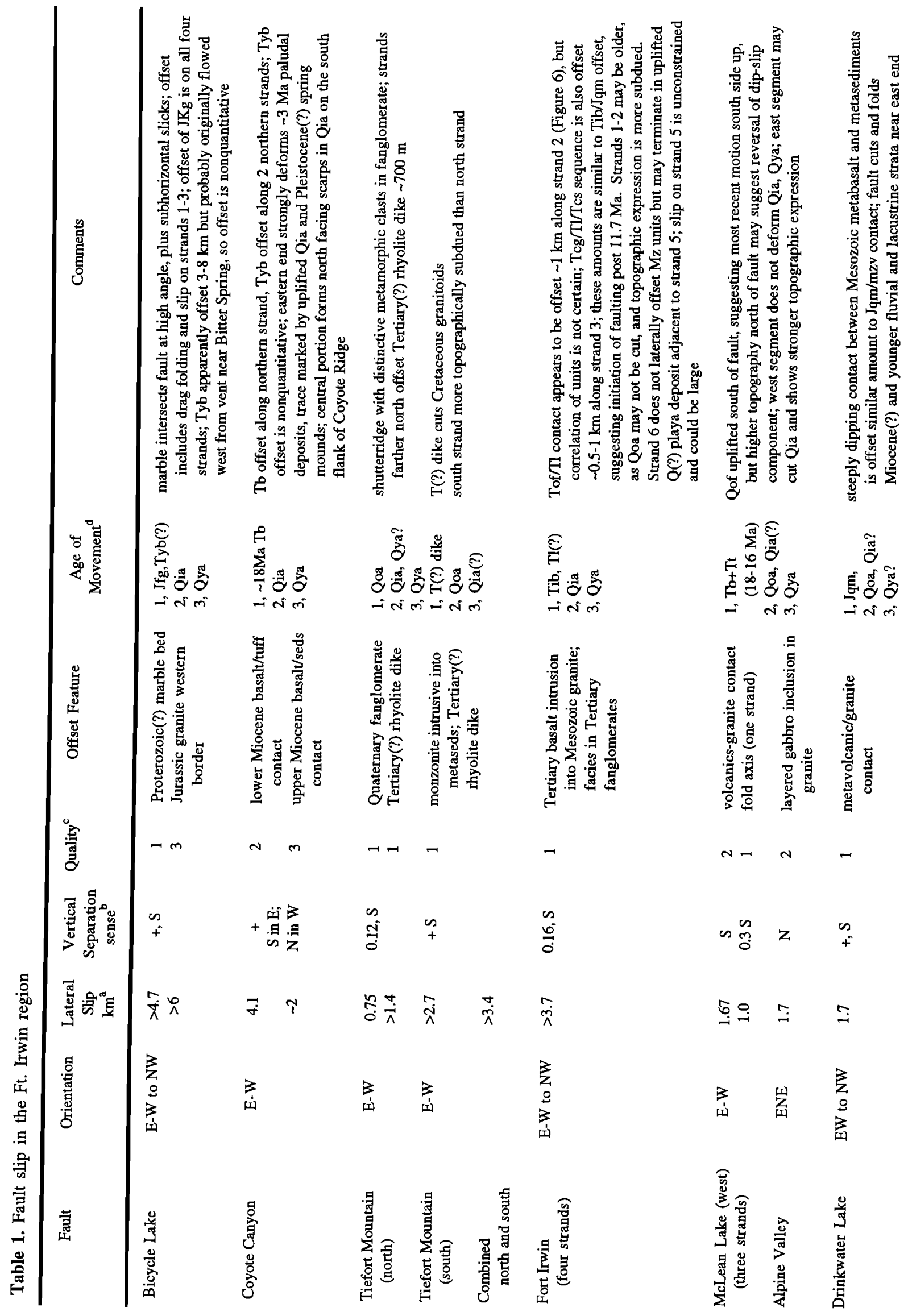




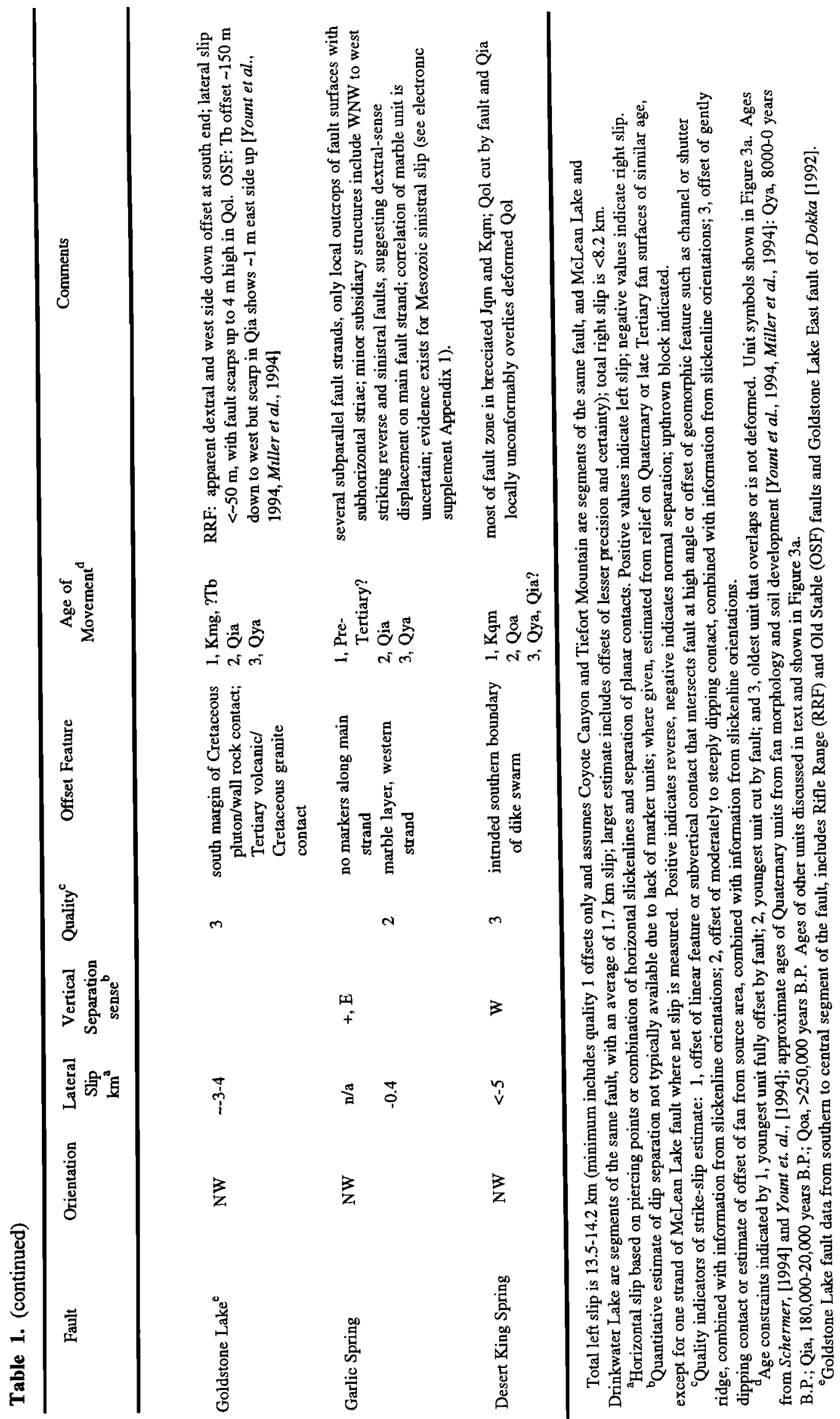


contrast to the large-magnitude extension in the central Mojave desert [Dokka, 1989; Glazner et al., 1989] and in the Avawatz Mountains [Spencer, 1990b]. Extension in the Avawatz Mountains was followed by late Cenozoic east vergent reverse faulting and folding that may be related to the eastern termination of the Garlock fault, or to right shear along northwest striking faults possibly connected to the southern Death Valley fault zone (Figures 1 and 2) [Brady, 1984b; Brady and Verosub, 1984; Brady and Dokka, 1989; Spencer, 1990a, b].

\section{Geometry and Kinematics of Faulting}

The Mojave block has long been recognized to contain at least two different Late Cenozoic structural domains, one containing northwest striking dextral faults and the other containing east striking sinistral faults [Garfunkel, 1974; Luyendyk et al., 1980, 1985; Carter et al., 1987]. More complex models of the domain structure have been proposed [Dokka and Travis, 1990a; Dokka, 1992], but in general, northwest or east striking strike-slip faults predominate in all models. Fort Irwin is located in a domain of east striking faults bounded to the east and west by north-northwest and northwest striking faults (Figure 2), but detailed structural studies have not been previously conducted in the region.

A summary of observations of faulting in Fort Irwin is shown in Table 1. Detailed maps and structural data are in Figures 3-9, and detailed fault zone descriptions are given in electronic supplement Appendix $1^{1}$. In general, east striking faults are typically subvertical to steeply south dipping, relatively continuous across Fort Irwin, and curve to northwest strikes at their east and west ends. Left-lateral strike-slip with a small reverse component occurs on east striking segments, and thrust or left-oblique slip occurs on the northwest striking end segments. The major east striking fault strands (Drinkwater Lake fault to McLean Lake fault; Fort Irwin fault; Tiefort Mountain fault to Coyote Canyon fault; and Bicycle lake fault; Figure 2) define four relatively coherent elongate crustal blocks. The east striking faults do not follow preexisting structural weaknesses (e.g., compare the trends of Mesozoic contacts and fabrics with faults on Figures 3, 4, and 5 ). Relatively continuous northwest striking faults are most important in western Fort Irwin and possibly at the eastern boundary of the domain, where they are less well exposed (Figure 1). A dextral component of slip is observed along northwest striking faults in northern and western Fort Irwin, including the Goldstone Lake, Desert King Spring, and Garlic Spring faults, but a dip-slip component is also present.

The relative quality of features used to estimate fault slip and separation is shown in Table 1, together with description of offset features. Few linear features are available to provide true piercing points; however, for planar features, we combine information from slickenlines and kinematic indicators on brittle fault planes together with measurement of separation on planes to assess the strike-slip and dip-slip components. If the slickenlines do not reflect the long-term fault history, this interpretation could be in error.

\footnotetext{
${ }^{1}$ Supporting Appendices 1 and 2 are available on diskette or via Anonymous FTP from kosmos.agu.org, directory APEND (Username = anonymous, Password = guest). Diskette may be ordered from American Geophysical Union, 2000 Florida Avenue, N W., Washıngton, DC 20009 or by phone at $800-966-2481 ; \$ 15.00$. Payment must accompany order.
}

\section{Detailed Structural Geology of Fault Zones}

Because of the complexity of many of the fault zones and the importance of distributed deformation within many of the fault blocks, we describe here in some detail the deformation along two of the major east striking fault zones, the Coyote CanyonTiefort Mountain fault system, and the Fort Irwin fault zone, and two of the northwest striking fault zones, the Goldstone Lake fault and Desert King Spring fault, which exemplify the most important features. Detailed maps of all the faults (Figures 3-9) and a summary of the age and nature of displaced units (Table 1) is supplemented by descriptions of deformation along the other faults in Appendix 1. The distributed deformation appears to play an important role in producing large rotations determined from paleomagnetic analysis relative to the amount of fault slip observed, as discussed below. We use subdivisions of Quaternary units following the criteria described by Yount et al., [1994] and Miller et al., [1994]; locations of the detailed maps are shown in Figure 2, and brief descriptions of widespread lithologic units are provided in Figure $3 \mathrm{a}$.

Coyote Canyon Fault. The Coyote Canyon fault strikes approximately east and extends from the Pink Canyon area in the west, across Coyote Ridge, to a likely connection with the Tiefort Mountain fault to the east (Figures 2 and 4). A distinct Miocene volcanic sequence of intercalated tuffs and basalts is offset across the fault zone. Cumulative strike separation on a contact between basalt and tuff near the base of the sequence is $4.1 \mathrm{~km}$ (Table 1 and Figure 4). Deformation along the Coyote Canyon fault is distributed in a zone $-1.5 \mathrm{~km}$ wide that includes most of Coyote ridge and Coyote Canyon and includes northwest plunging folds and reverse faults (Figure 4).

The western termination of the Coyote Canyon fault occurs where it is truncated by the Goldstone Lake fault (Figure 9). In this region the several fault strands curve into a more northwesterly orientation, suggesting dextral drag related to the Goldstone Lake fault [MacConnell et al., 1994]. At its east end, the fault is buried beneath Holocene alluvium.

Tiefort Mountain fault (north and south). The Tiefort Mountain fault strikes east from the northern margin of Tiefort Mountain and bifurcates into northern and southern strands at eastern Tiefort Mountain (Figures 2 and 5). Abundant steeply dipping brittle fault planes with subhorizontal slickensides demonstrate dominantly strike slip (Figure 5). East trending folds are common adjacent to the northern strand, and there appears to be a significant component of south-side up reverse faulting near the eastern end (Table 1). To the west, the sense of vertical separation appears to change to south-side down normal faulting. The change from reverse to normal dip-slip component may be related to the presence of a releasing bend in the area of North Tiefort Ridge, where the main strand of the fault changes strike $-10^{\circ}$ (Figure 5 and Table 1). Offset markers include irregular pre-Tertiary intrusive contacts and a vertical Tertiary(?) rhyolite dike (solid triangle pattern on Figure 5), indicating sinistral slip of $>3.4 \mathrm{~km}$ on the major north and south strands, but the northernmost strand on the north flank of North Tiefort Ridge may accommodate additional slip (Table 1 and Figure 5). An offset Quaternary alluvial fan deposit with distinctive metamorphic clasts forms a shutter ridge along the northern strand that indicates $750 \mathrm{~m}$ sinistral slip since early Pleistocene time (Figure 5). This evidence, together with the strong topographic expression of the north strand, suggests that the northern 


\section{EXPLANATION OF MAP SYMBOLS}

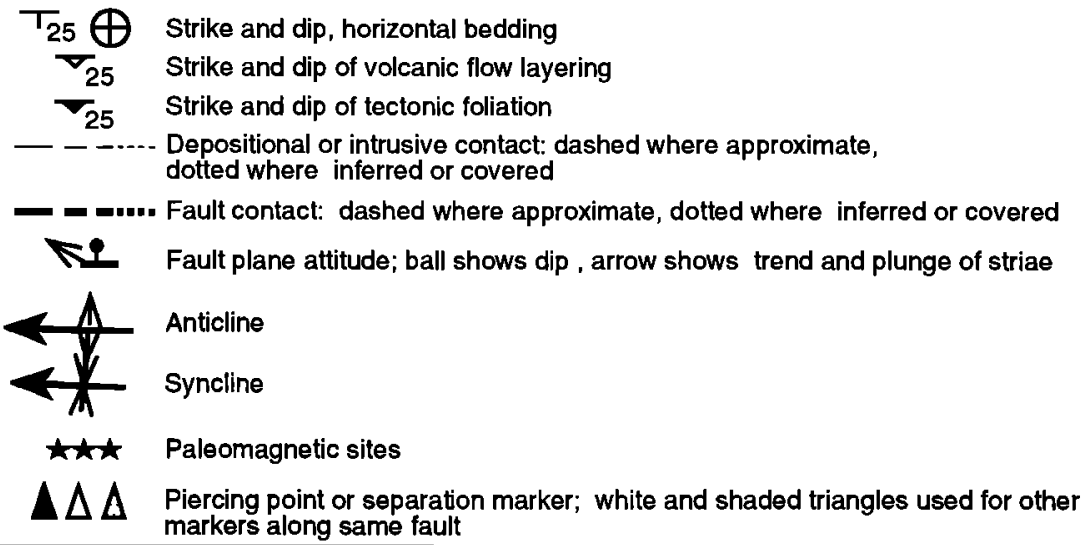

\section{EXPLANATION OF MAP UNITS}

Qya Qp. Holocene wash and alluvial fan deposits (Qya) and playa deposits (Qp)

$\because \because$ Pleistocene alluvial deposits showing desert pavement and rock varnish

Qia. development, moderately developed soils. Qia/Qoa indicates younger fan developed on older deposits. Age probably 20-180ka (Yount et al., 1994)

Pleistocene alluvial fan deposits showing well developed or eroded soils, moderately incised and eroded fan morphology. Age probably >250ka (Yount et al., 1994).

Qitf Pleistocene and Pliocene(?) alluvial fan deposits, moderately indurated, with strongly eroded soils and highly dissected fan morphology; locally probably older than Tyb. Age $>500 \mathrm{ka}$ (Yount et al, 1994).

Yyb Younger basalt: Latest Miocene (5.6 Ma) andesitic basalt

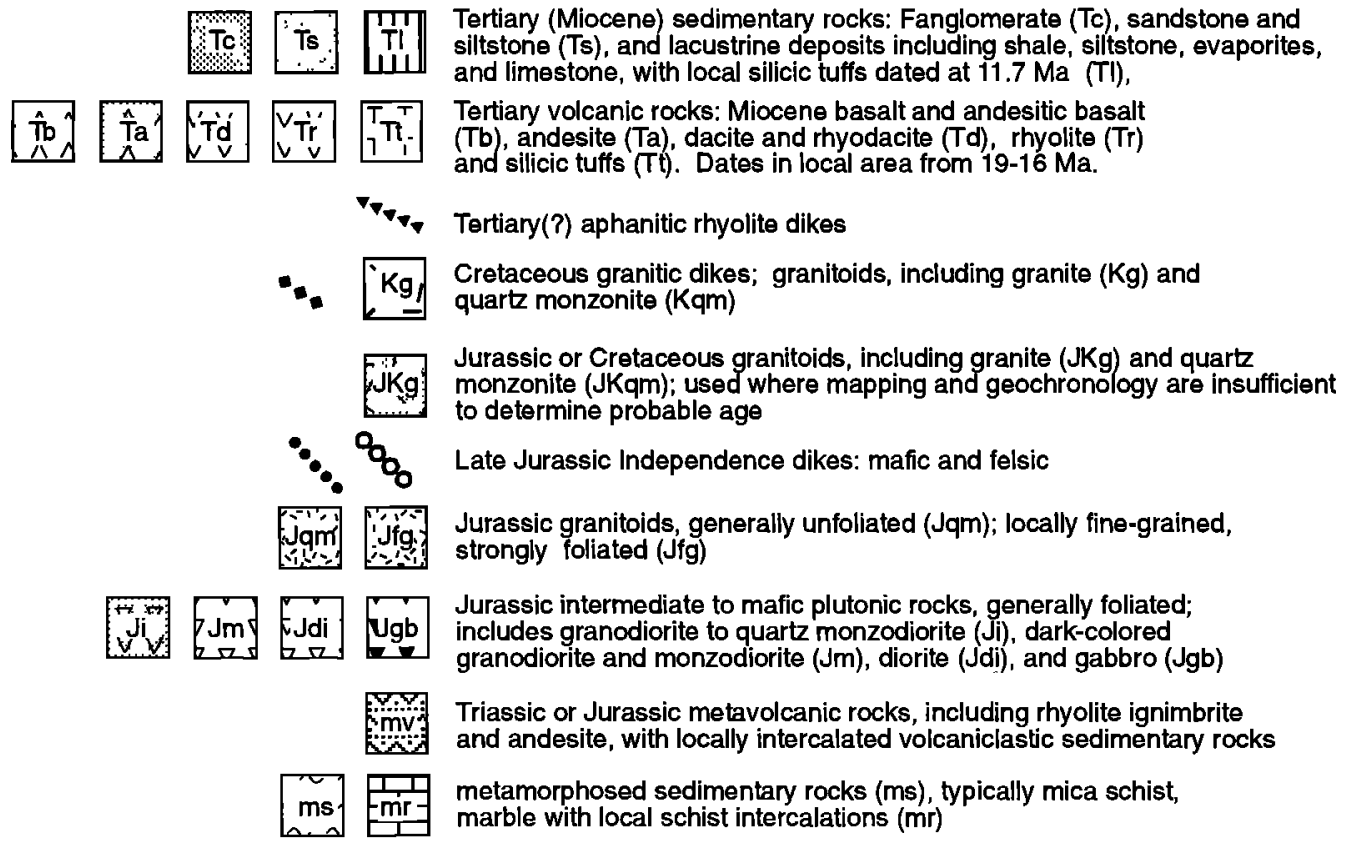

Figure 3a. Explanation of map units and symbols used in Figures 3b-9. Only lithologic units that are present on more than one map are shown here; units of restricted importance are identified in individual figures. Ages based on Ar/Ar data from Schermer [1994, also unpublished data, 1994]; subdivision of Quaternary units after Yount et al. [1994]. 


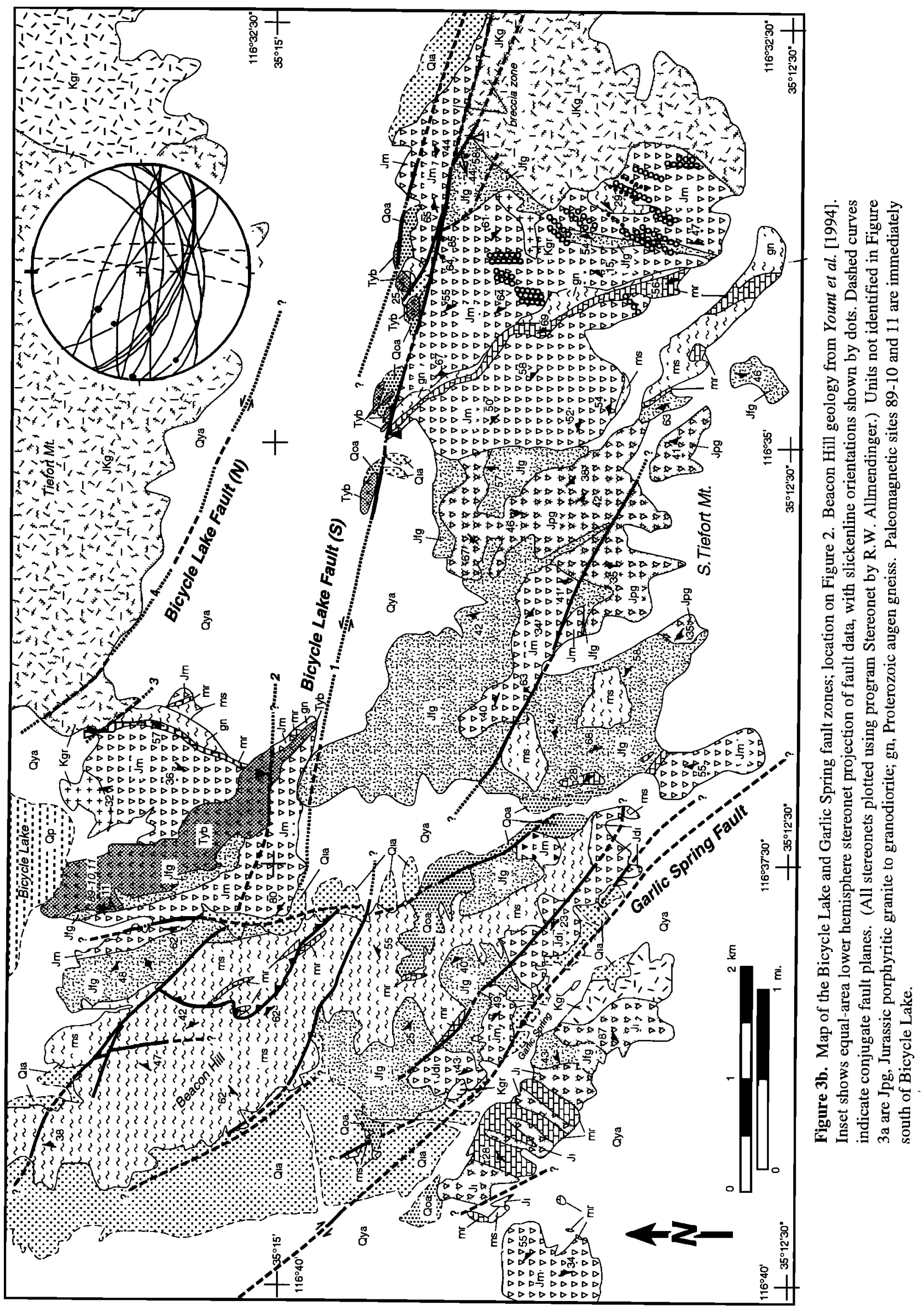




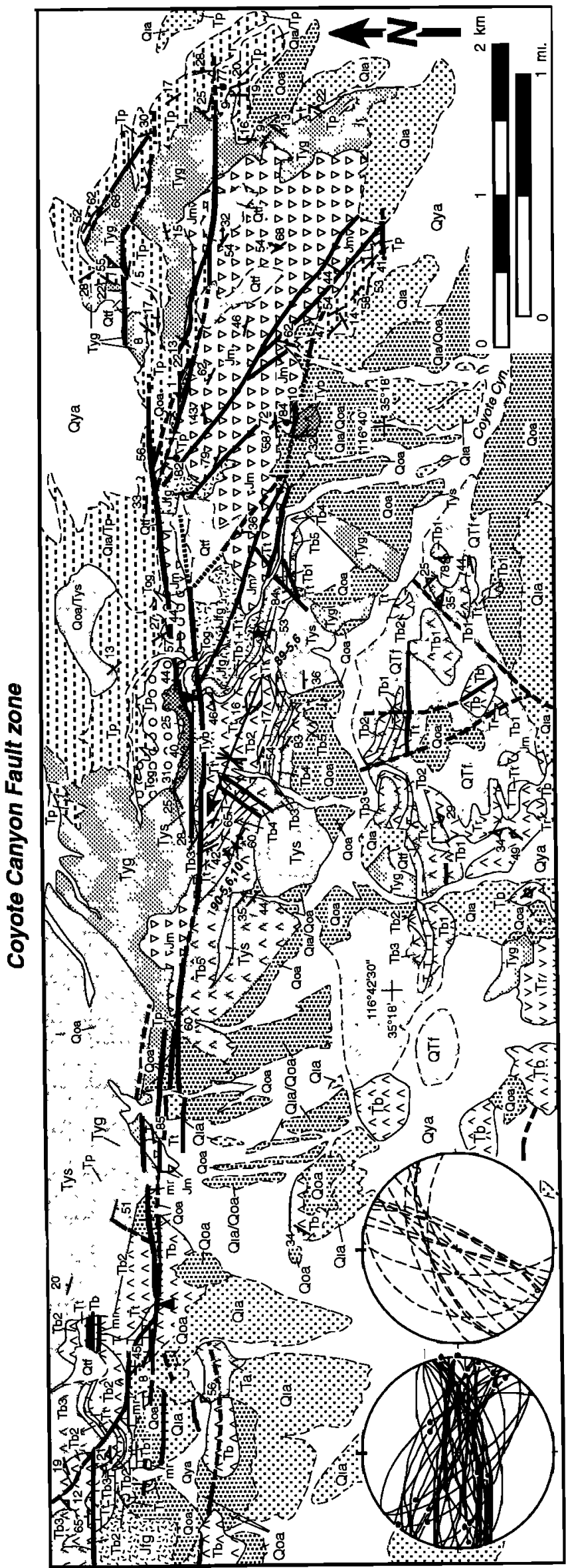

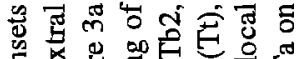

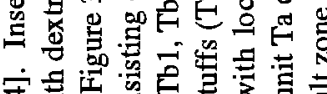

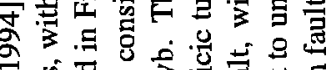

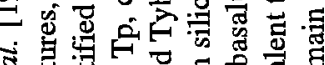

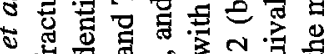
\$

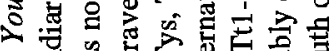

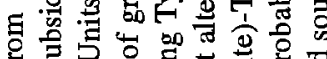

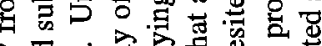

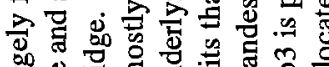

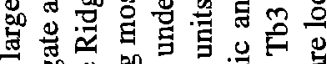

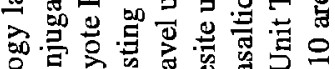

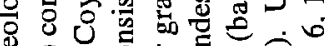

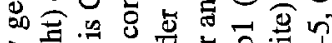

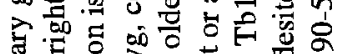

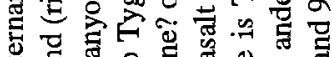

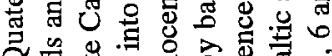

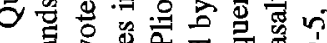

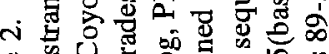

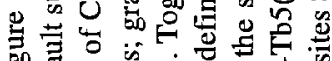

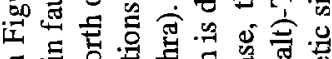

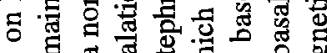

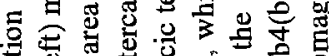

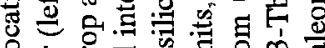

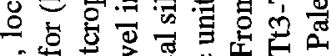

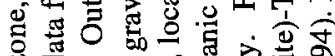
응 मे

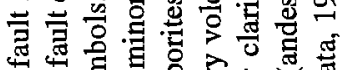

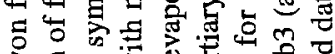
रे

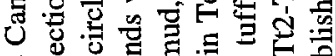

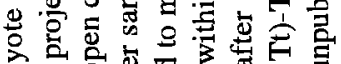

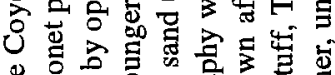

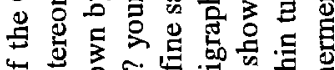

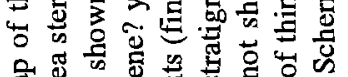

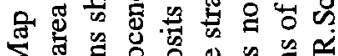

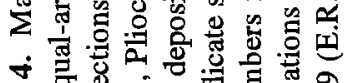

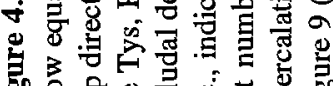

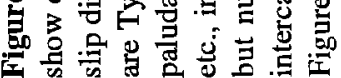




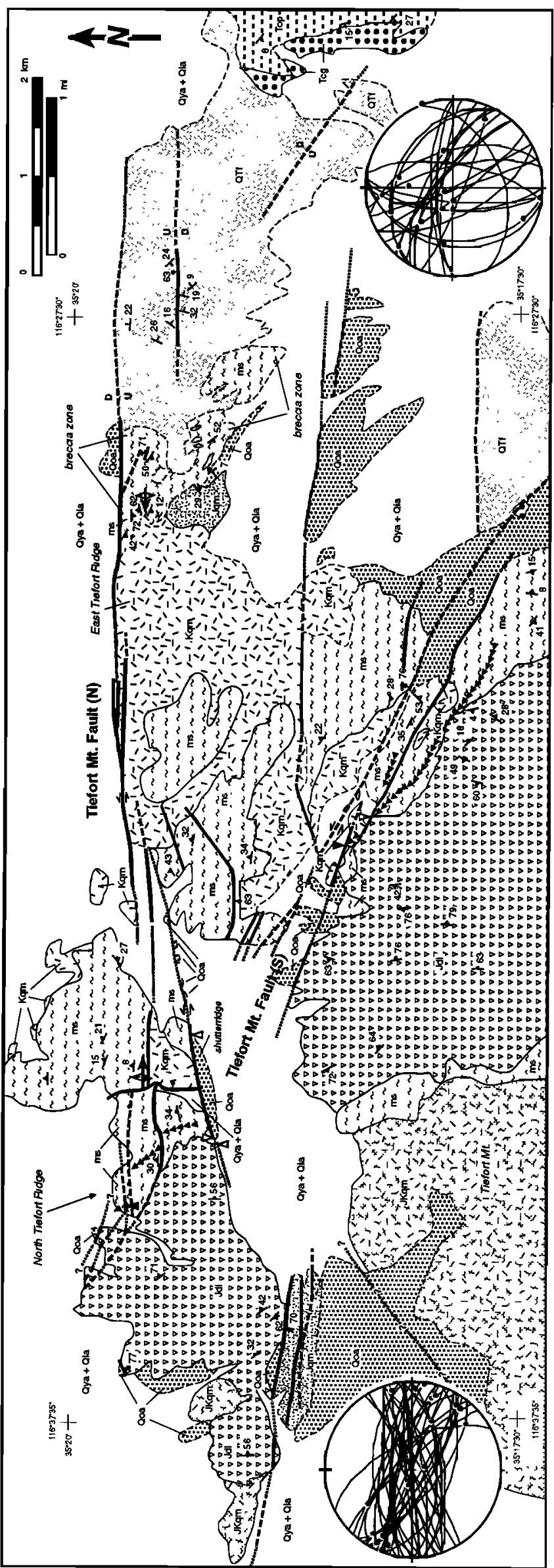

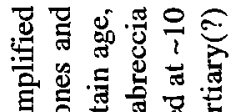

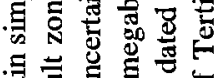

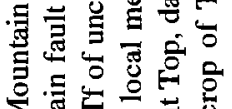

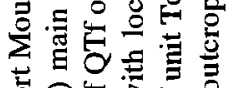

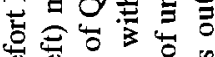

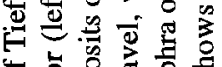

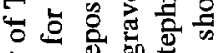
察焉

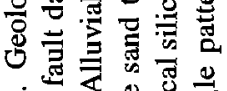

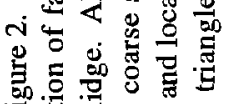

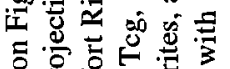

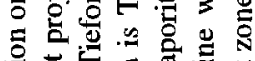
鹿得

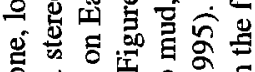

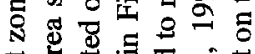

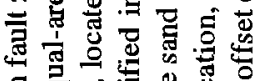

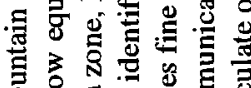

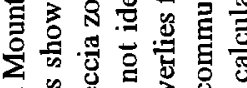

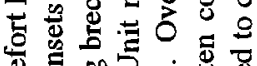

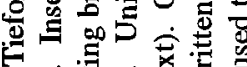
安要

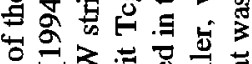

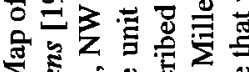

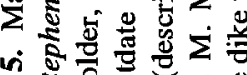

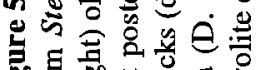

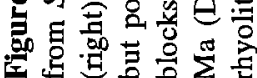




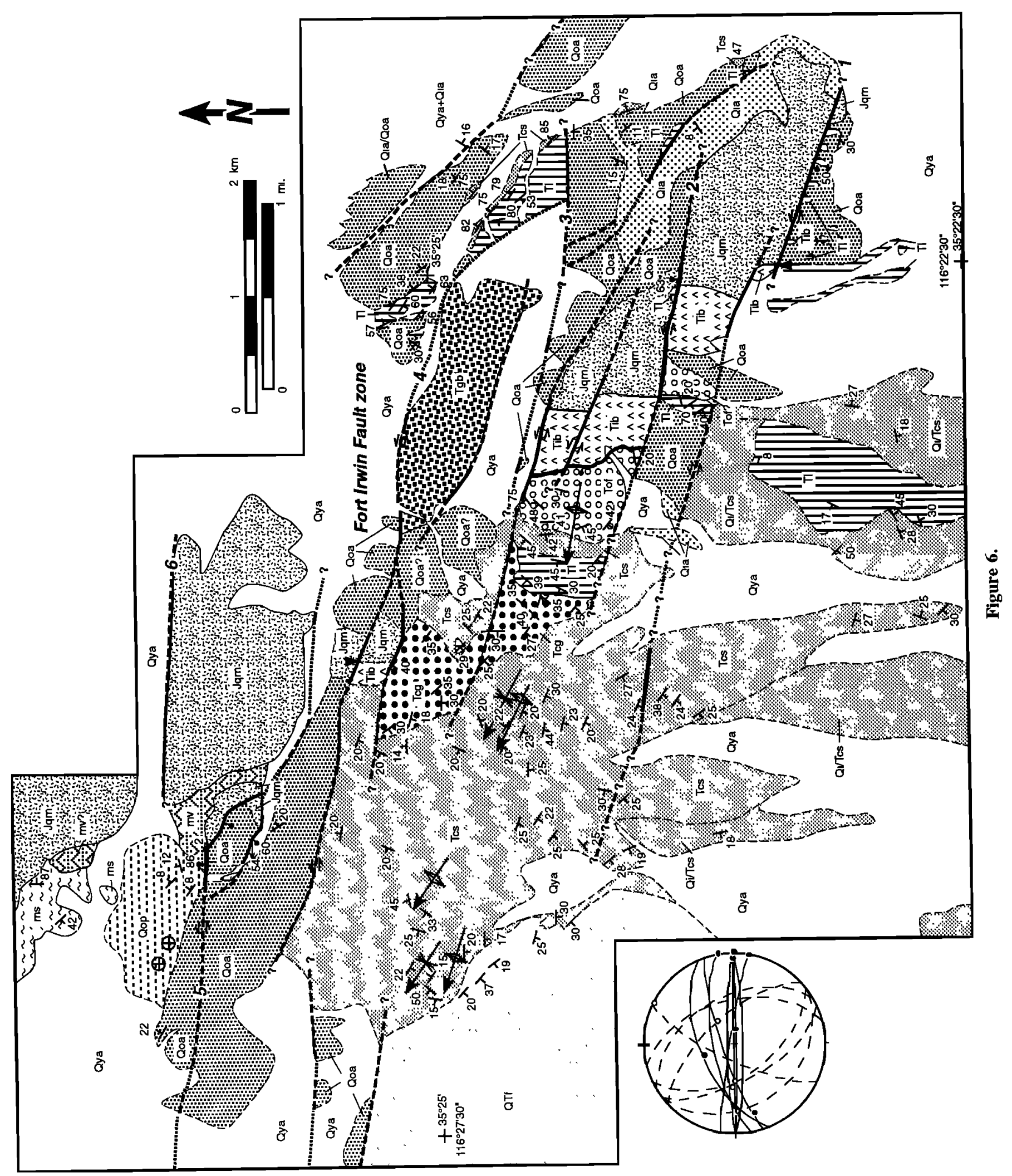


strand is younger than the southern strand. Additional evidence consistent with this interpretation is the steep topographic gradient and $\sim 750 \mathrm{~m}$ of relief on the north flank of Tiefort Mountain, suggesting the presence of an older south strand beneath the uplifted and dissected fans (Figure 5). Further evidence of a reverse fault bounding Tiefort Mountain comes from a well drilled through alluvial fans on the northwest flank, which is interpreted to show granitic rocks of Tiefort Mountain thrust northward above alluvium (R. Quinones, personal communication, 1992).

A complex breccia zone of northwest striking faults at East Tiefort Ridge contains both northeast and southwest dipping dipslip and strike-slip faults (Figure 5, right inset) that are overlain unconformably by early Quaternary or late Tertiary fan deposits (QTf) and are cut by the Tiefort Mountain fault (N). This suggests that either the northwest trending breccia zone is an older, unrelated feature or that earlier strands of the Tiefort Mountain fault may once have curved to northwest strikes but were later crosscut by east striking strands. Coarse fanglomerate and breccia dated at <19 Ma [Sobieraj, 1994] and megabreccia sheets interpreted as landslide deposits overlie $\sim 10 \mathrm{Ma}$ fluvial and lacustrine deposits south and east of the Tiefort Mountain fault (D. Miller, written commication 1995) (unit Tcg, Figure 5). These deposits were derived from East Tiefort Ridge and eastern Tiefort Mountain [Sobieraj, 1994] and suggest the presence of major topographic relief bordering a basin east of Tiefort Mountain. Because faults are not exposed at either margin of the basin, it is difficult to determine whether these landslide deposits are related to normal, thrust, or strike-slip faulting (see Appendix 1, "Red Pass faults" for further description of the Tertiary deposits).

Fort Irwin fault. The Fort Irwin fault extends from just west of the Avawatz Mountains to west of Nelson Lake (Figure 2). Details of the western extent in the Nelson Lake area are uncertain because the fault is covered by alluvium and land has been extensively modified (due to military activity), so the area described herein includes only the segment east of the Granite Mountains. The fault was first recognized [Jennings et al., 1962] to have $\sim 2 \mathrm{~km}$ left separation of a contact between a Tertiary? basalt plug and Jurassic or Cretaceous granite. Our more detailed studies document the existence of six fault strands (numbered on Figure 6) with subhorizontal slickenlines indicating cumulative left-slip on the exposed intrusive contact of $>3.7 \mathrm{~km}$ [Sobieraj, 1994; Sobieraj and Schermer, 1994]. Contacts between different units within the $<11.7 \mathrm{Ma}$ Miocene fan deposits are offset (strands 2 and 3 ), and the available evidence suggests that these Miocene deposits are offset as much as the older rocks (Table 1), thus constraining the initiation of faulting to post $\sim 11 \mathrm{Ma}$ [Schermer, 1994; Sobieraj, 1994]. Strand 5 cuts Quaternary alluvial and playa deposits, dips steeply south, and has a component of reverse as well as left slip, indicated by both topography and slickenline data (Figure 6). Several strands of the Fort Irwin fault bend to a northwest strike at its eastern end and accommodate a component of northeast vergent thrusting and folding (Figure 6). However, whether the easternmost segments merge with or are cut by northwest striking faults farther east is uncertain because northwest striking faults are not well exposed. Along the western extension of the Fort Irwin fault in the Nelson Lake area, there appears to be left separation of Tertiary volcanic units across several linear, east striking ridges of uplifted alluvial and volcanic deposits (Table 1, Figure 2, and Appendix 1). Pyroxene dacite that crops out northwest of McLean Lake may have been derived from a dome/vent complex of similar pyroxene dacite southeast of Nelson Lake (Figures 2 and 7a), which would allow for $>7.5 \mathrm{~km}$ left separation across the Nelson Lake and McLean Lake faults.

Goldstone Lake and associated faults. Faults at the western boundary of the Northeast Mojave Domain mapped in this study include the Main Gate fault, the Old Stable Fault, and the Rifle Range fault, together with reconnaissance observations along the Goldstone Lake fault (Figure 9) [also see Dokka, 1992; Miller et al., 1994; Yount et al., 1994]. The Rifle Range fault, Main Gate fault, and Old Stable Fault are likely related.strands of the Goldstone Lake (east) fault of Dokka [1992], but connections and relations have yet to be established by direct mapping, and the southeastern extent of all the faults is uncertain. The Main Gate fault is marked by a subvertical northwest striking breccia zone in Jurassic and Cretaceous plutonic rocks. Two sets of fractures with subhorizontal slickensides occur along one segment of the fault (Figure 9), one that strikes approximately east with dextral kinematic indicators and the other that strikes northwest with poorly developed sinistral kinematic indicators. Net slip on the fault is poorly constrained due to lack of distinctive marker units and presence of similar Cretaceous granite on both sides of the fault. A crude estimate of $\sim 4 \mathrm{~km}$ of dextral separation is provided by the offset of the gently dipping contact between Tertiary volcanic rocks and Cretaceous granite, but this is not a unique contact relation. A contact between Cretaceous muscovite-garnet granite and Jurassic quartz diorite mapped west of the area of Figure 9 by Miller and Sutter [1982] may be the offset equivalent of the contact east of the Main Gate fault, which would suggest $\sim 3 \mathrm{~km}$ dextral separation (Figure 9), but the plutonic rocks may not be equivalent, as Yount et al., [1994] suggested the Cretaceous granite is offset in a sinistral sense.

Figure 6. Map of eastern Fort Irwin fault zone, location on Figure 2. Subdivisions of Tertiary units modified from Sobieraj [1994]. Inset shows equal-area stereonet projection of fault data: main fault planes and slickenline orientations shown with solid lines and solid symbols; conjugate and subsidiary faults and slickenline orientations shown by dashed lines with open symbols. For clarity, not all folds are shown by fold symbols, but can be identified from bedding attitudes. Bold numbers indicate different strands of fault referred to in text. Tertiary lacustrine deposits (unit $\mathrm{Tl}$ ) north of strand 4 dated at $11.7 \pm 0.1 \mathrm{Ma}$ [Sobieraj, 1994]. Units not identified in Figure 3a are Qop, older(?) Quaternary playa deposits, incised by modern wash; Tcs, Tcg, interfingering finer (sandstone to cobble conglomerate) and coarser (pebble to boulder conglomerate) Miocene alluvial fan deposits; Tof, conglomerate with different clast compositions from Tcs, Tcg [see Sobieraj, 1994]; Tib, hypabyssal intrusive basaltic andesite. 


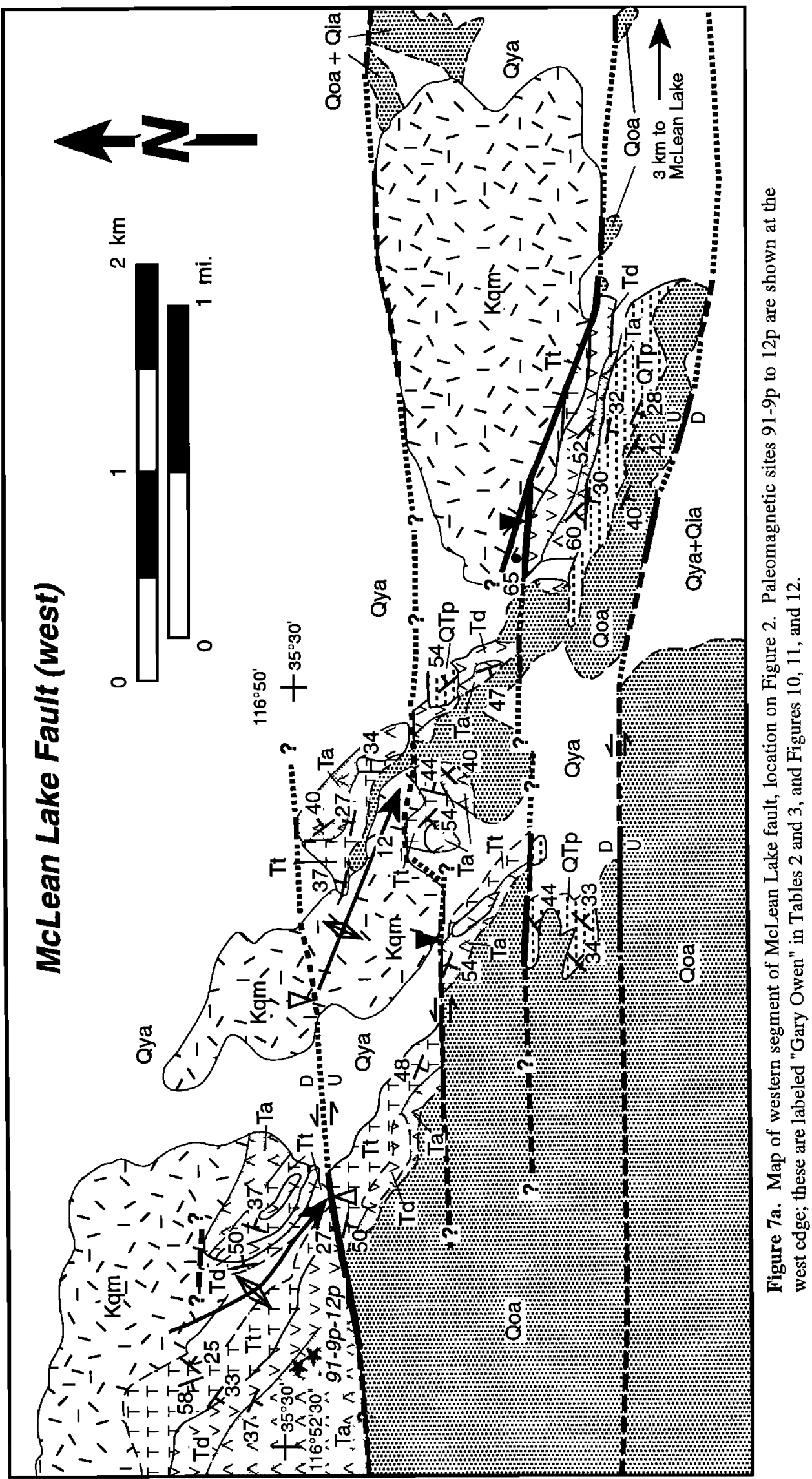




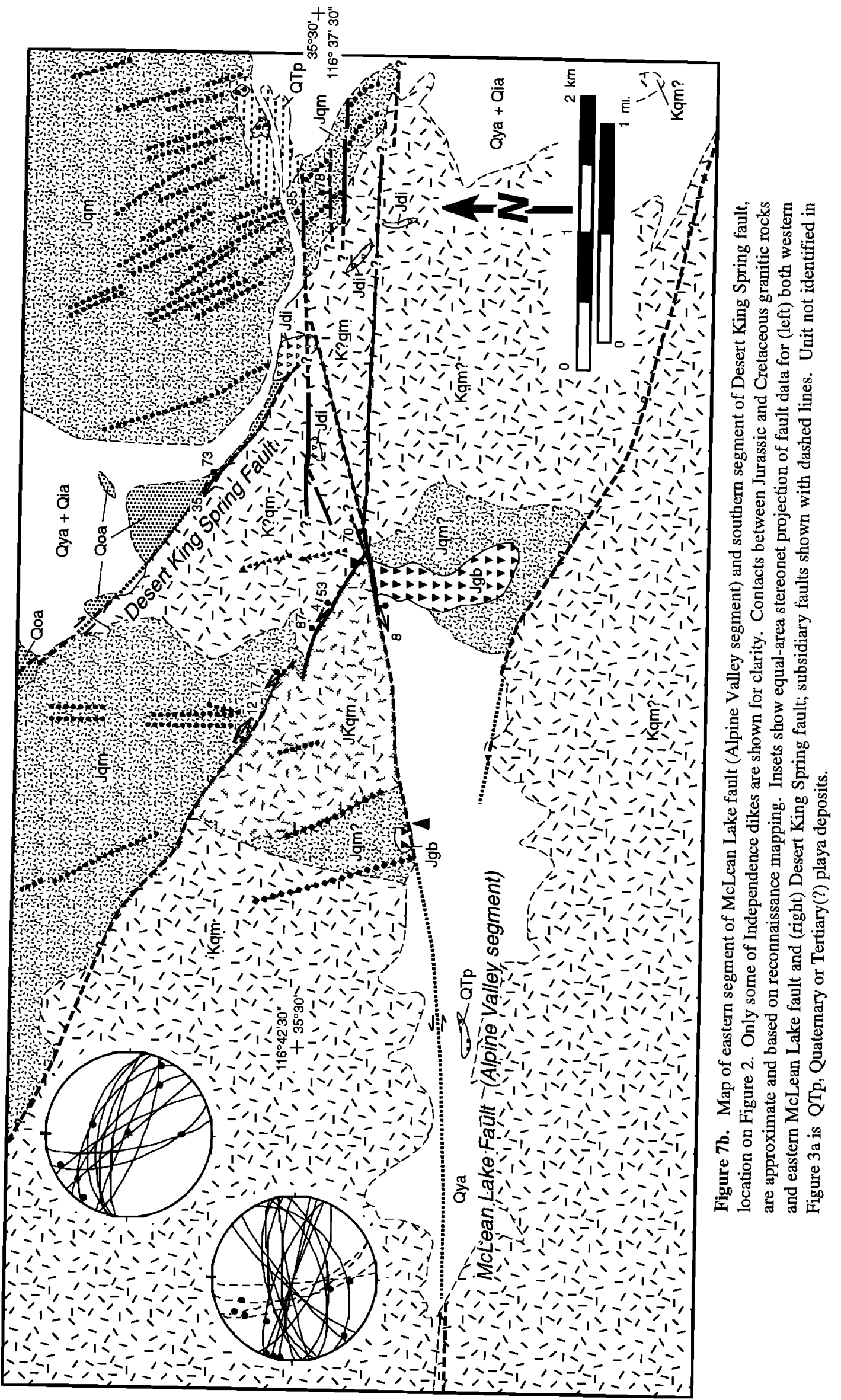




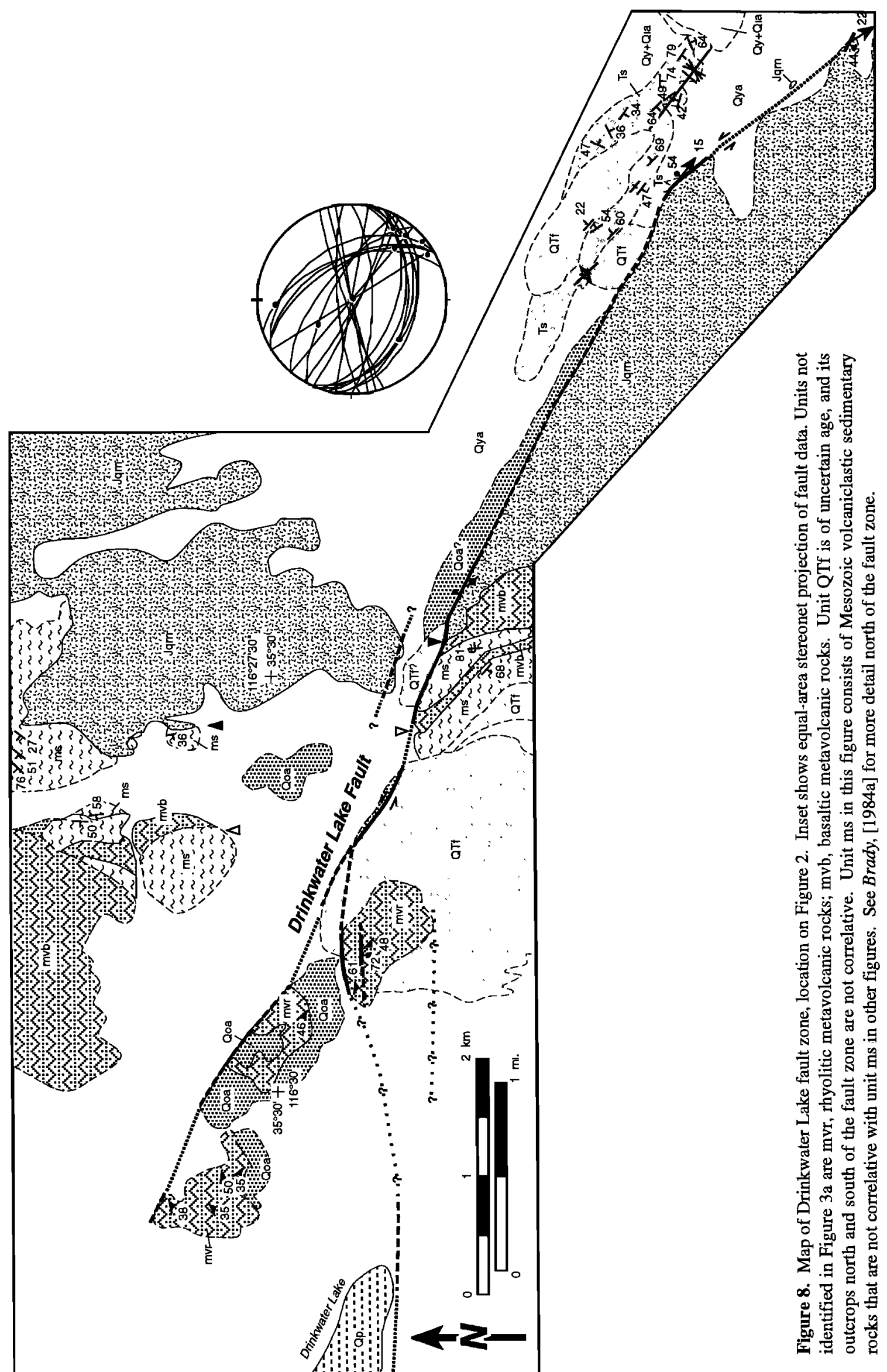




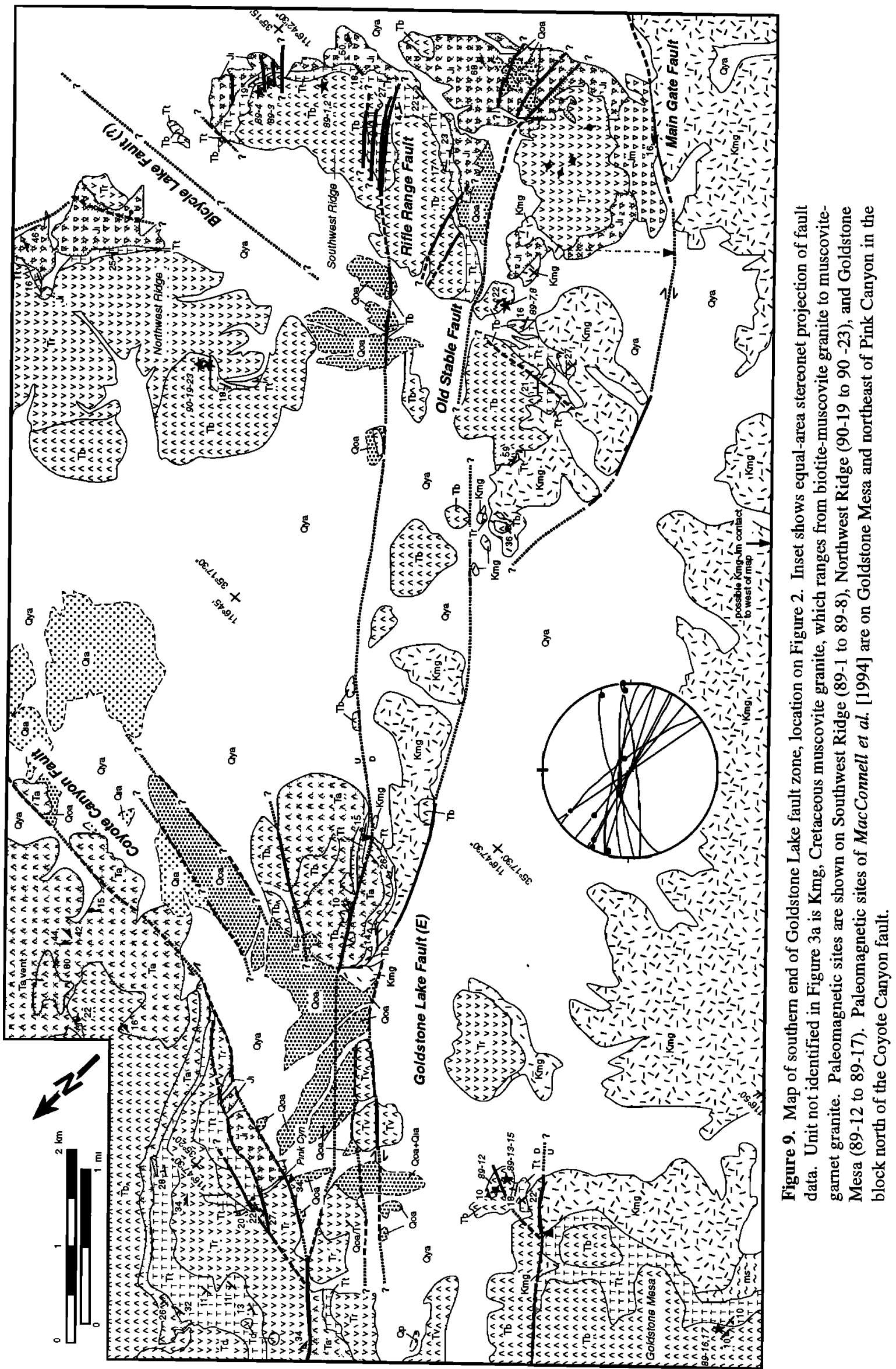


Dokka [1992] proposed $\sim 2.5 \mathrm{~km}$ dextral slip on the Goldstone Lake fault but did not indicate the offset units. The Old Stable Fault strikes north-northwest and curves to more northerly strikes in several splays at its southern end (Figure 9). Yount et al., [1994] interpret the splays as either a horsetail splay at the termination of a dextral fault or curved due to the margin of a rhyolite plug southwest of the fault. The Rifle Range fault consists of several strands with minor lateral and dip-slip displacement (<100 m [Miller et al, , 1994; Yount et al., 1994]). Farther to the northwest, the Goldstone Lake (east) fault appears to cut the Coyote Canyon fault. MacConnell et al., [1994] report $\sim 28^{\circ}$ of clockwise rotation of Miocene volcanic rocks north of the Coyote Canyon fault and east of the Goldstone Lake fault and attribute the rotation to dextral bending along the Goldstone Lake fault, consistent with our observations of the change in strike of volcanic rocks (Figures 4 and 9). Strands of the Goldstone Lake fault that cut Goldstone Mesa (Figures 2 and 9) show evidence for $\sim 0.5 \mathrm{~km}$ of right separation and $\sim 100-150 \mathrm{~m}$ vertical separation (northeast side down) of the gently north dipping contact between the basalt and Cretaceous granitic rocks.

Desert King Spring fault. The Desert King Spring fault (Figure 7b) was interpreted to be a right-lateral fault by Dokka and Travis, [1990a] and Dokka, [1992], though no evidence was cited for amount or sense of displacement. The fault is marked by a breccia zone that cuts through Jurassic and Cretaceous rocks, but no markers exist in the Quaternary units cut by the fault (Figure 7b and Table 1). Slickenlines and small-scale kinematic indicators are sparse. Because the fault zone juxtaposes identical granitic rocks cut by the Independence dike swarm on either side and does not appear to significantly displace the southern, intruded boundary of the dike swarm, dextral slip is likely $<5 \mathrm{~km}$ (Figure $7 \mathrm{~b}$ ). Moreover, the Desert King Spring fault is clearly cut by several small-displacement splays of the Alpine Valley fault (Figure $7 \mathrm{~b}$ ), which has $<2 \mathrm{~km}$ of cumulative left-lateral slip on it. Thus if the Desert King Spring fault is a long, continuous fault, its offset continuation south of the Alpine Valley fault should appear farther southeast in the Granite Mountains. Although no detailed mapping has been done in that part of the Granite Mountains, no evidence for the fault can be seen on aerial photos, on Landsat TM images, or in reconnaissance mapping. A northwest striking fault with subhorizontal slickensides occurs just west of the Desert King Spring fault and has apparent left separation of a contact between Jurassic and Cretaceous granite (Figure 7b); however, the kinematics and timing of this fault and its relation to the Desert King Spring fault are uncertain. Thus the $24 \mathrm{~km}$ dextral slip on the Desert King Spring fault predicted by Dokka, [1992] remains unverified. Part of the basis for the large slip value was the purported existence of a large sphenochasm basin northeast of the fault. However, we have mapped outcrops of basement rocks in small hills and gullies within the alluvial fan complex northeast of the fault (Figure 2; also shown by Jennings et al., [1962] ), and limited gravity data [Nilsen and Chapman, 1971; Saltus and Jachens, 1995] show no evidence for a low. These observations suggest that the area northeast of the Desert King Spring fault contains a thin veneer of alluvium or pediment over shallow granite basement rather than a large deep basin.

\section{Discussion of Geometric Characteristics of Faulting}

Size of fault blocks. The detailed mapping of the fault zones and areas between major faults described above and in Appendix
1 reveals that deformation is distributed over several kilometers adjacent to each fault zone. The five major east striking faults, the Garlock, Drinkwater Lake-McLean Lake, Fort Irwin, Tiefort Mountain, and Bicycle Lake faults, divide the region into blocks $\sim 7-10 \mathrm{~km}$ wide by $40-50 \mathrm{~km}$ long, which we term "crustal blocks" (Figure 2). Typically, $0.5-1 \mathrm{~km}$ of the north and south edge of each block is occupied by complexly deformed rocks in the bounding fault zones, but the width of deformed rock increases to $2-3 \mathrm{~km}$ adjacent to fault jogs and bends. The faults tend to have multiple strands, and rocks are folded and sheared within the fault zone and adjacent to each strand; these define "local" blocks. Local blocks are also defined by the intersection of subsidiary northwest and northeast striking faults with the main fault zones (e.g., Figures 3, 4, and 6). The east striking faults typically have cumulative sinistral slip of $3-5 \mathrm{~km}$ that is distributed between the several fault strands in addition to a significant component of reverse slip (Table 1). Thus, in our consideration of the regional significance of the deformation in the northeast Mojave domain, a simple plane strain model of crustal blocks bounded by discrete, single, strike-slip faults is clearly too simple.

While it is evident from this study that the area of deformed rock is significant relative to the block size, there are still undeformed areas $-5-10 \mathrm{~km}$ wide between each fault zone. Although a single marker unit is rarely present in more than one crustal block, nearly all the blocks (with the exception of the block between the Tiefort Mountain fault and the Fort Irwin fault) have geologic features that can be traced the entire width of the block, suggesting that no significant slip is accommodated on unrecognized faults within the blocks. Furthermore, most of the markers used to measure slip have been followed across the deformed block edges; thus the slip values reflect cumulative displacement across the deformed zones. Disappearance of marker units from one fault block to another, however, leaves open the possibility that unrecognized or buried faults exist at the edges of the blocks that could accommodate more slip. We consider this unlikely, however, due to the overall continuity of such features as the belt of Mesozoic metavolcanic rocks, the Independence dike swarm, and the belt of Jurassic mylonitic rocks (Figures 2 and 10). In some areas, however, the width of undeformed blocks appear to be $<5 \mathrm{~km}$, for example, in the Nelson Lake area and north of Red Pass Lake (Figure 2). Elsewhere, where Quaternary units cover significant portions of the fault block (e.g., north of Tiefort Mountains), the only constraint on true block size is for the faults that have been active during Quaternary time (all of those in Table 1), and it is possible there was a more complex pattern of faulting during earlier times.

Fault intersections. Deformation at the ends of fault blocks occurs at the intersections of northwest and east striking faults. Unfortunately, many of these intersections in Fort Irwin occur in areas of low hills of sedimentary rocks that are poorly exposed. Fairly simple crosscutting relations are exhibited at the intersection of the Goldstone Lake and Coyote Canyon faults (Figure 9) where the Coyote Canyon fault curves to a more northwesterly strike and rocks adjacent to the fault are interpreted to be folded due to dextral drag on the Goldstone Lake fault [MacConnell et al., 1994]. Fault intersections farther north along the Goldstone Lake fault are not well exposed, but both the Nelson Lake fault and McLean Lake fault appear to be crosscut by the Goldstone Lake fault in areas of uplifted Quaternary and Tertiary sedimentary rocks. The intersection of the Bicycle Lake 


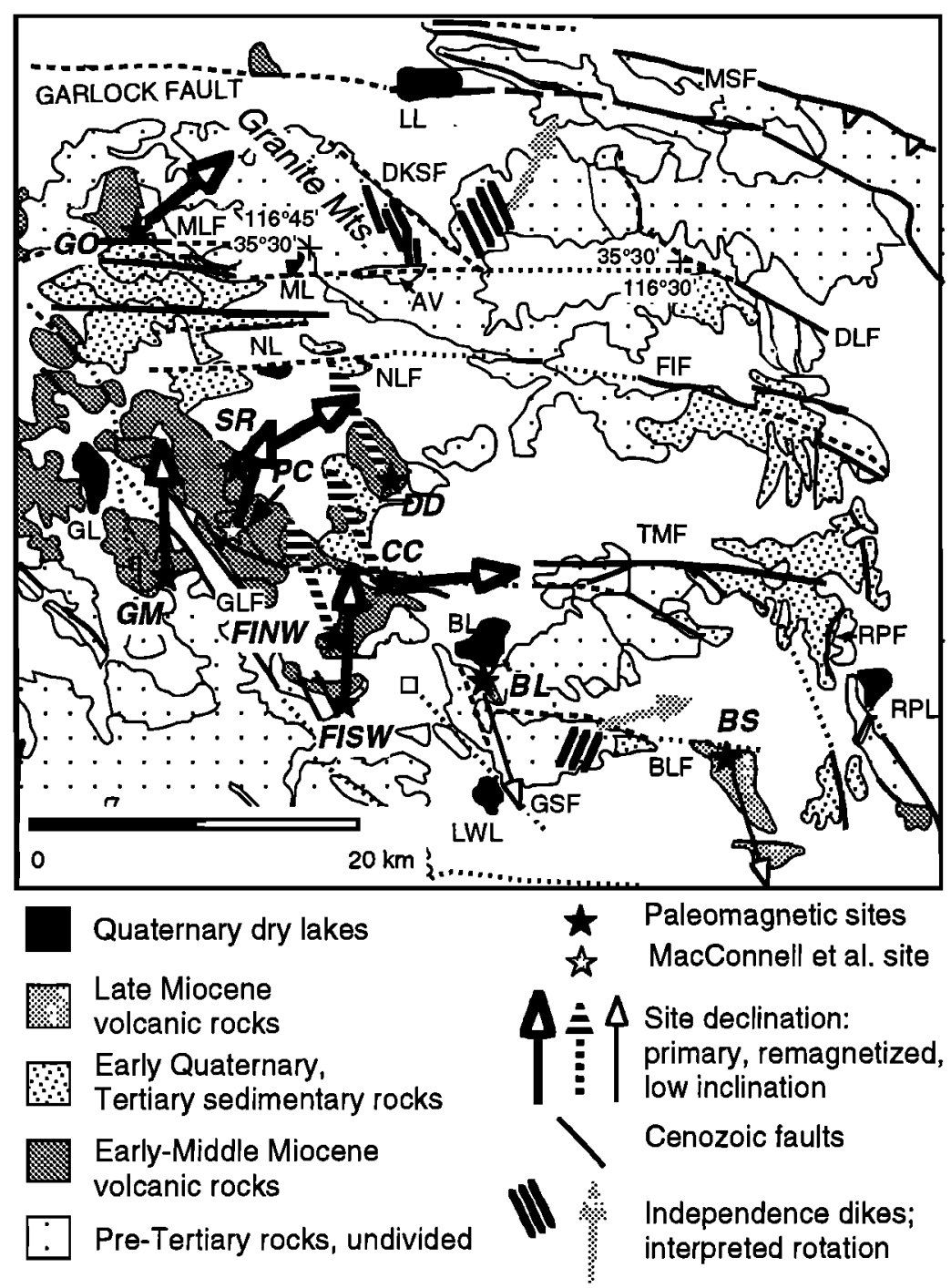

Figure 10. Map of the Fort Irwin region showing the location of paleomagnetic sampling locations, mean declination direction at each location (Table 2), and outcrops of the Independence Dike Swarm. Independence dike trends are used to interpret rotation of Fort Irwin outcrops (arrows) relative to dike outcrops north of the Garlock fault (see text). Site location abbreviations are BL, Bicycle Lake; BS, Bitter Spring; CC, Coyote Canyon; DD, Dacite Dome; FINW, Fort Irwin Northwest (Northwest Ridge); FISW, Fort Irwin Southwest (Southwest Ridge); GM, Goldstone Mesa; GO, Gary Owen; PC, Pink Canyon location of MacConnell et al. [1994]; SR, Stone Ridge. Other abbreviations as in Figure 2. Declination arrow shown for BL and BS is an average for these localities (see text).

and Garlic Spring fault is extremely complex and is manifested by a zone of thrusting, folding, and both sinistral and dextral faulting that makes up most of Beacon Hill (Appendix 1 and Figure 3) [Miller et al., 1994; Yount et al., 1994]. At the intersection of the Desert King Spring fault and the Alpine Valley strand of the McLean Lake fault, mapped fault traces indicate that the McLean Lake fault cuts the Desert King Spring fault and splays out into many strands with small (tens to hundreds of meters) displacement (Figure 7b).

At the eastern margin of the domain, the northwest striking faults east of Tiefort Mountain, including the southern strand of the Tiefort Mountain fault and the Red Pass faults (Figure 2) are cut by the north strand of the Tiefort Mountain fault in a zone of intense brecciation and complex faulting (Figures 2 and 5). It is unclear whether the complexity of deformation in this region is related to the intersection of broadly coeval faults. It is also possible that the northwest trending fabrics are related to an earlier deformation associated with the shedding of megabreccias into the adjacent basin. The eastern ends of the other east striking faults bend to northwest strikes and develop a significant thrust or reverse component before they are cut by northwest striking faults (Figures 6 and 8). It is unclear whether any large northwest striking dextral faults exist within or east of the Avawatz Mountains at the eastern boundary (Appendix 1).

In general, the fault intersections in the study area appear to result in transpression and positive relief, as opposed to the 
formation of extensional basins such as the sphenochasms that have been inferred to mark the ends of blocks [e.g., Luyendyk et al., 1980; Carter et al., 1987; Dokka, 1992]. In eastern Fort Irwin, where low-relief areas are present at the ends of the blocks, any basin formed there may be related to overthrusting of units to the east. Modeling of gravity data [Saltus and Jachens, 1995] suggests that basins exist at the east ends of the fault blocks, and the abundance of Miocene and Pliocene(?) deposits in this area (Figure 2) may indicate that long-lived basins developed at the ends of the blocks. Whether these late Neogene basins are due to extension or shortening is unknown, but they appear to largely postdate the Avawatz formation and its associated extensional event [Sobieraj, 1994; Spencer, 1990b].

\section{Timing of Faulting}

The major faults in the northeast Mojave domain were active during post-middle Miocene through Quaternary time. Early Miocene volcanic rocks (18-16 Ma) [Schermer, 1994] appear to be displaced as much as Paleozoic and Mesozoic rocks, suggesting faulting began after $\sim 16 \mathrm{Ma}$. Along the Fort Irwin fault, sediments $<11.7 \mathrm{Ma}$ appear to have been offset as much as older rocks [Sobieraj, 1994]. These data are consistent with the

Table 2. Mean Paleomagnetic directions for Fort Irwin

\begin{tabular}{|c|c|c|c|c|c|c|c|c|}
\hline Location & Site & Age, ${ }^{\mathrm{a}} \mathrm{Ma}$ & $\mathrm{N}$ & I, D, deg & Polarity $^{\mathrm{b}}$ & $\alpha_{95}$ & $\mathbf{k}$ & $\mathbf{R}$ \\
\hline Dacite Dome & $\begin{array}{l}84-1,2 ; \\
91-13,15,16\end{array}$ & $\begin{array}{l}17.68 \pm 0.24 \\
(90-37 a) \\
15.8 \pm 0.4 \\
(90-101)\end{array}$ & 5 & $\begin{array}{l}69.1,332.7 \\
\text { uncorrected }\end{array}$ & $\mathbf{N}$ & 12.2 & 40.5 & 4.901 \\
\hline Fort Irwin SW & $89-1,3,4,7$ & $\begin{array}{l}17.83 \pm 0.2 \\
(89-2)\end{array}$ & 4 & $\begin{array}{l}46.4,3.3 \\
\text { corrected }^{\mathrm{c}}\end{array}$ & $\mathbf{N}$ & 15.5 & 36.1 & 3.917 \\
\hline $\begin{array}{l}\text { Coyote Canyon } \\
\text { NW declinations }\end{array}$ & $90-5,90-6$ & & 2 & $\begin{array}{l}45.3,334.6 \\
\text { conrected }^{\mathrm{d}}\end{array}$ & $\mathrm{N}$ & & & \\
\hline $\begin{array}{l}\text { Coyote Canyon } \\
\text { NE declinations }\end{array}$ & $89-5,90-10$ & $\begin{array}{l}17.9 \pm 1.0 \\
\left(89-5^{f}\right) \\
17.1 \pm 0.4 \\
(89-6)\end{array}$ & 2 & $\begin{array}{l}54.7,83.8^{\mathrm{c}} \\
\text { corrected }^{\mathrm{g}}\end{array}$ & $\mathbf{R}$ & & & \\
\hline $\begin{array}{l}\text { Bicycle Lake and Bitter } \\
\text { Springs, combined }\end{array}$ & & $\begin{array}{l}5.57 \pm 0.26 \\
(89-11) \\
5.5 \pm 0.2 \\
(91-16 p)\end{array}$ & 5 & $\begin{array}{l}8.7,163.1 \\
\text { corrected }^{h}\end{array}$ & $\mathrm{~T}$ ? & 14.2 & 30.1 & 4.867 \\
\hline Goldstone Mesa & $89-12$ to $89-18$ & $\begin{array}{l}17.4 \pm 0.4 \\
(89-14) \\
18.4 \pm 0.2^{\mathrm{J}}\end{array}$ & 7 & $\begin{array}{l}43.6,357.8 \\
\text { corrected }^{\mathrm{i}}\end{array}$ & $\mathbf{N}$ & 5.7 & 112.0 & 6.946 \\
\hline Stone Ridge & $90-11$ to $90-16$ & $\begin{array}{l}18.6 \pm 0.5 \\
(90-14) \\
21.0 \pm 1.1 \\
\left(90-14^{\mathrm{f}}\right)\end{array}$ & 6 & $\begin{array}{l}57.9,59.5 \\
\text { uncorrected }\end{array}$ & $\mathbf{N}$ & 5.4 & 153.0 & 5.967 \\
\hline Fort Irwin NW & $90-19$ to $90-23$ & $\begin{array}{l}18.0 \pm 0.2 \\
(90-23)\end{array}$ & 5 & $\begin{array}{l}59.0,339.6 \\
\text { uncorrected }\end{array}$ & $\mathbf{N}$ & 12.9 & 36.0 & 4.889 \\
\hline Gary Owen & $91-9 p$ to $91-12 p$ & $\begin{array}{l}15.85 \pm 0.11 \\
(91-9 p)\end{array}$ & 4 & $\begin{array}{l}46.7,50.0^{\circ} \\
\text { corrected }^{1}\end{array}$ & $R^{k}$ & 14.0 & 44.2 & 3.932 \\
\hline
\end{tabular}

$\mathrm{N}$ is number of sites comprising 3 to 6 samples each. Lavas at Dacite Dome, Stone Ridge, and Fort Irwin NW are believed to be flat-lying and no structural corrections were applied. At Fort Irwin SW, the average of site mean directions corrected for fold plunge and bedding dip yields $\alpha_{95}=15.5^{\circ}$ and $\mathrm{k}=36.1(\mathrm{n}=4)$; the average of uncorrected in situ site mean directions yields $\alpha_{95}=25.4^{\circ}$ and $\mathrm{k}=14.0$. The mean directions for the northeast declination group and for the north-to-northwest declination group include both structurally corrected and in situ site mean directions. The same group means computed with all uncorrected site mean directions have much higher values of $\alpha_{95}$ and lower values of $k ; \alpha_{95}=42.0^{\circ}$ and $k=2.0$ for northeast declination sites, and $\alpha_{95}=8.4^{\circ}$ and $k=14.1$ for the north- to northwest-declination sites. These analyses suggest a successful modified fold test indicating magnetization was acquired before structural disturbance.

${ }^{a}$ E. Schermer and P.B. Gans (unpublished data, 1994), except where otherwise indicated. Sample number in parentheses.

bolarity: N, normal; R, reversed; T?, transitional?

${ }^{c}$ Structural attitudes $221^{\circ} / 22^{\circ} \mathrm{NW}, 89-1 ; 190^{\circ} / 19^{\circ} \mathrm{NW}, 89-3,4340^{\circ} / 25^{\circ} \mathrm{NE}, 89-7 ;-1,-3,-4$ plunge $16^{\circ}$ at $354^{\circ}$

${ }^{\mathrm{d}}$ Structural attitudes $126^{\circ} / 60^{\circ} \mathrm{SW}$, plunge $22^{\circ}$ at $290^{\circ}$

${ }^{c}$ calculated with reversed directions projected through the origin

${ }^{f} \mathrm{~K}$-Ar by Geochron Labs.

${ }^{\mathrm{g}}$ Structural attitudes $111^{\circ} / 53^{\circ} \mathrm{S}, 89-5$, plunge $22^{\circ}$ at $290^{\circ}$

${ }^{\mathrm{h}}$ Structural attitudes $240 \% 11^{\circ} \mathrm{NW}$, Bike Lake; $349^{\circ} / 6^{\circ} \mathrm{E}$, Bitter Springs

${ }^{i}$ Structural attitudes $290^{\circ} / 10^{\circ} \mathrm{N}, 89-12 ; 302^{\circ} / 18^{\circ} \mathrm{NE}, 89-14,15 ; 182^{\circ} / 16^{\circ} \mathrm{W}, 89-16,17,18$

${ }^{j}$ cited by MacConnell et al. [1994]

${ }^{\mathbf{k}}$ Except $91-12$ is $\mathbf{N}$.

${ }^{1}$ Structural attitudes $126^{\circ} / 37^{\circ} \mathrm{SW}$, plunge $27^{\circ}$ at $163^{\circ}$ 
Table 3. Fort Irwin Mean Directions, Virtual Geomagnetic Poles, and Discordance

\begin{tabular}{llccccccc}
\hline \multicolumn{1}{c}{ Site Group } & N & I, D, deg & $\begin{array}{c}\alpha_{95} \\
\text { deg }\end{array}$ & $k$ & $R$ & VGP & \multicolumn{2}{c}{ Discordance $^{\mathrm{b}}$} \\
\hline Northeast & 12 & $54.2,59.7$ & 6.6 & $44.4^{\circ}$ & 11.750 & $41.9^{\circ} \mathrm{N}, 315.8^{\circ} \mathrm{E}$ & $63.5^{\circ} \pm 7.6^{\circ} \mathrm{CW}$ & $2.6^{\circ} \pm 6.3^{\circ}$ south $^{\text {Rotation }}$ \\
North and NW & 23 & $53.6,349.8$ & 6.3 & 24.4 & 22.099 & $81.5^{\circ} \mathrm{N}, 148.5^{\circ} \mathrm{E}$ & $6.5^{\circ} \pm 7.4^{\circ} \mathrm{CCW}$ & $2.1^{\circ} \pm 6.1^{\circ}$ south \\
$\quad$ North & 11 & $44.6,359.7$ & 5.5 & 68.7 & 10.854 & $80.9^{\circ} \mathrm{N}, 65.1^{\circ} \mathrm{E}$ & $3.5^{\circ} \pm 6.3^{\circ} \mathrm{CW}$ & $5.9^{\circ} \pm 5.6^{\circ}$ north \\
$\quad$ NW, Remagnetized? & 12 & $61.0,336.2$ & 8.0 & 30.2 & 11.636 & $70.3^{\circ} \mathrm{N}, 180.6^{\circ} \mathrm{E}$ & $20.0^{\circ} \pm 9.5^{\circ} \mathrm{CCW}$ & $10.0^{\circ} \pm 7.2^{\circ}$ south \\
\hline
\end{tabular}

${ }^{a}$ Bitter Springs and Bicycle Lake excluded; $n=5$ sites. Two dominant directions are selected; northeast or clockwise deflected and northwest or counterclockwise deflected. Northeast sites are Coyote Canyon 89-5, 90-10; Stone Ridge 90-11 to 90-16; and Gary Owen 91-9 to 91-12. North and NW sites are all good sites minus the NE sites above. North sites are Fort Irwin SW 89-1, 3, 4, 7; Goldstone Mesa 89-12 to 89-18. NW, remagnetized? sites are Dacite Dome 84-1, 84-2, 91-13, 91-15 and 91-16; Coyote Canyon 90-5, 90-6; and Fort Irwin NW 90-19 to 90-23.

${ }^{b} \mathrm{CW}$, clockwise; CCW, counterclockwise. Discordance is relative to early and middle Miocene reference pole of Calderone et al., [1990] at $85.5^{\circ} \mathrm{N}, 108.9^{\circ} \mathrm{E}, \alpha 95=4.4^{\circ}: \mathrm{I}=51.4^{\circ} ; \mathrm{D}=356.2^{\circ}$ at Fort Irwin. Calculated with formulae of Butler [1992] and [Demarest, 1983].

${ }^{c}$ If the means of the locations with $\mathrm{NE}$ declinations (Table 2) are averaged together ( $\mathrm{n}=3$ ) the mean direction result has $\mathrm{k}=46.0$ compared to 44.4. Both of these values are too high for proper averaging of secular variation [Butler, 1992].

suggestion of Dokka and Travis [1990a,b] that faulting in the Mojave block began at 6-10 Ma. Rocks as young as middle Pleistocene, and locally Holocene [Miller et al., 1994], are deformed along many of the faults; however, no quantitative estimate of Quaternary slip is available except along the Tiefort Mountain fault (Table 1). Seismicity in the region is sparse, although it has increased since the Landers earthquake (Southern California Seismographic Network, unpublished data, 19921994). Modern drainages and fan surfaces are not cut by faults, except along the Garlock fault. If the faults are active, long recurrence intervals may be likely, given the subdued topographic expression of the faults and lack of offset of the youngest Quaternary units. Long recurrence intervals $\left(10^{3}-10^{4}\right.$ years) have also been proposed for northwest striking faults in the Landers rupture area and the central part of the Eastern California shear zone [Wallace, 1984; Lindvall and Rockwell, 1993; Sauber et al., 1994; Rockwell et al., 1995; C.M. Rubin and K. Sieh, unpublished manuscript, 1995]. There is no systematic crosscutting relationship between the northwest and east striking faults, and both sets cut similar age Quaternary deposits, suggesting both sets are approximately coeval.

\section{Paleomagnetism}

\section{Sampling and Results}

We obtained oriented drill core samples from 50 sites in Miocene basalts, andesites, and dacites in the region (Figure 10, Table 2, and electronic supplement Appendix 2). All specimens were treated by step-wise alternating field demagnetization (AFDM) and their stable directions were selected by line fitting to orthogonal vector end point diagrams. Two direction groups defining northeast and north-to-northwestward declinations were found in 35 sites that were of acceptable quality (Table 2 and Figure 11). Of these sites, five are reversely polarized and are deflected southwest approximately antipodal to the northeast deflected sites, suggesting a successful reversal test.

At any given location the number of direction results is too few to average secular variation (Table 2). Successful field stability tests include the approximate reversal test mentioned above and modified fold tests indicating that magnetization was acquired before structural disturbance (Table 2).

The stable characteristic paleomagnetic directions do not appear to bear a simple relation to the elongate crustal blocks such as is seen for the California Transverse Ranges [e.g., Carter et al., 1987; Luyendyk, 1991]. The combined north and northwest declinations are close to the expected direction for a middle Miocene North American paleomagnetic pole determined for the southeast California-western Arizona region [Calderone et al., 1990] (Table 3 and Figure 11). However, the mean

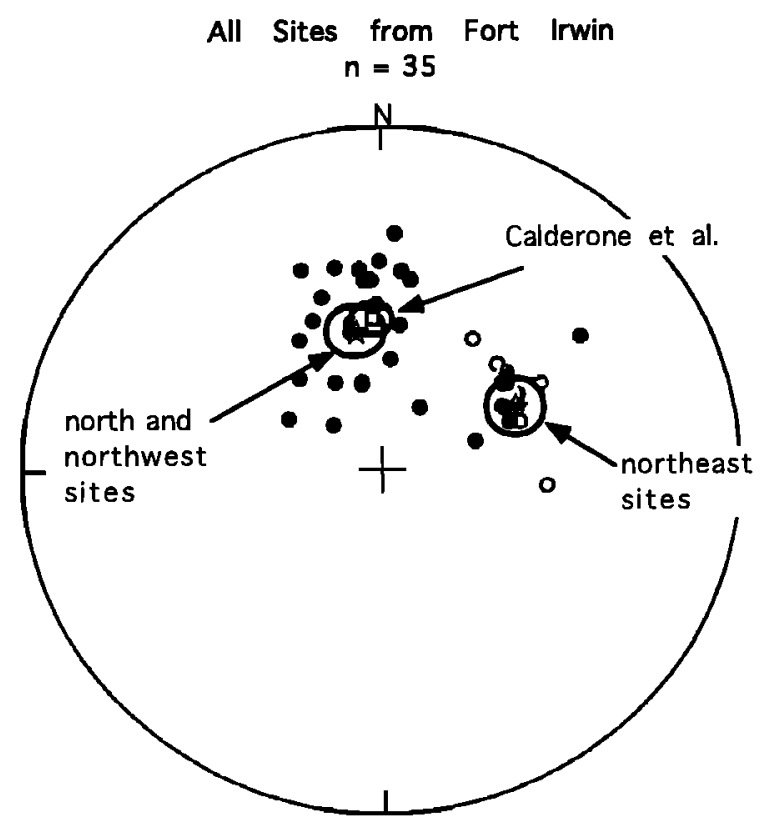

Figure 11. Equal-area diagram of paleomagnetic site mean directions for the 35 units studied. Also shown are the mean directions for northeast declination and north-to-northwest declination sites (see text) and the Miocene reference direction from Calderone et al. [1990]. Solid circles indicate normal polarity; open circles indicate reversed polarity directions. 
AF demagnetization of 90-15.2a from Stone Ridge

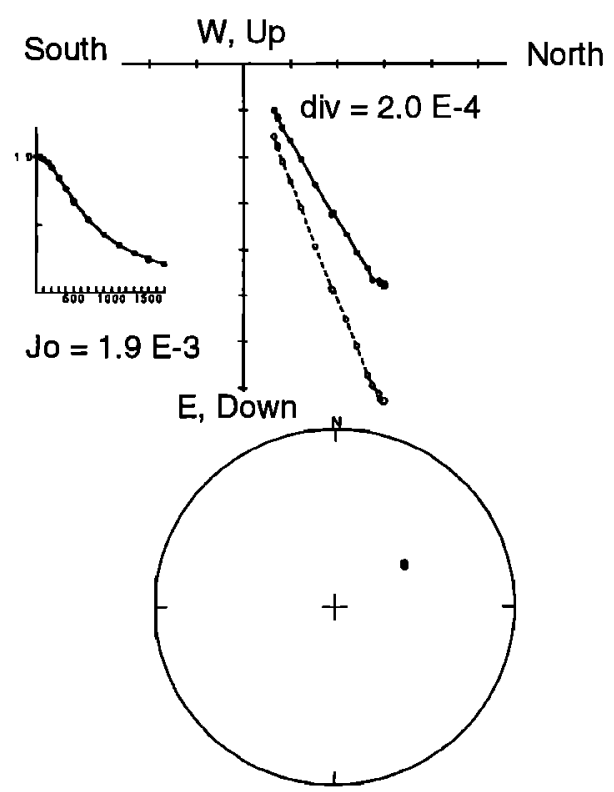

b AF demagnetization of 90-22.1 from Ft. Irwin NW

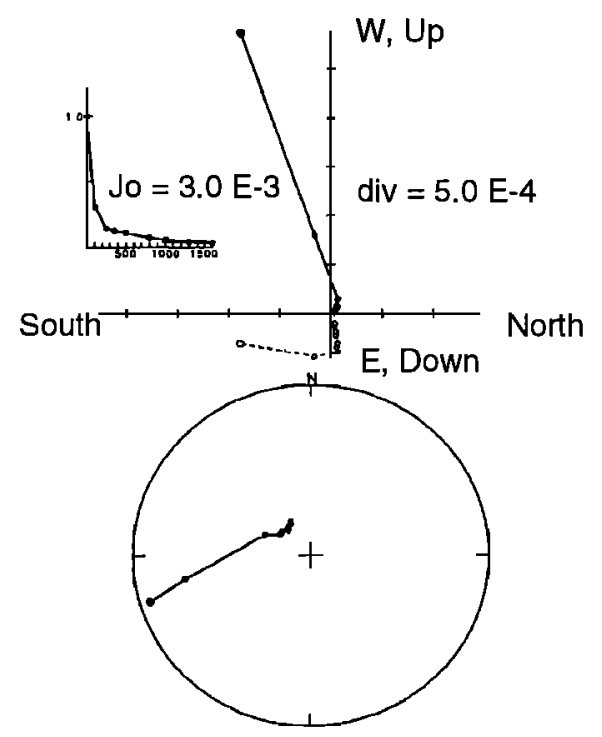

Figure 12. Progressive alternating field demagnetization data for representative samples from (a) Stone Ridge (90-15.2) and (b) Northwest Ridge (90-22.1). These samples demonstrate the two classes of demagnetization behavior: hard with a stable characteristic remanent magnetization (Stone Ridge), and soft with streaked directions found at northwest declination sites (Fort Irwin NW).

direction from all the northwest declination sites alone has good precision statistics and is discordant counterclockwise from the Miocene reference pole (Table 3 ). The northeast directions are $63.5^{\circ} \pm 7.6^{\circ}$ clockwise from the reference pole.

\section{Progressive Demagnetization Studies}

Progressive AFDM experiments reveal two classes of behavior: (1) a large amplitude soft component removed by 15 $\mathrm{mT}$ or less $(150 \mathrm{Oe})$; and (2) resistance to AFDM with a median destructive field greater that several tens of milliteslas (Figure 12). Most samples from most locations are of type 1. These softer samples have streaked directions on equal-area plots. Soft samples are from a variety of rock types and ages and often show multiple overprint directions. Many harder samples also show a reversed overprint direction on their natural remanent magnetization (NRM) that is removed by $10 \mathrm{mT}$. The AFDM shows the most resistant samples are from Goldstone Mesa and Stone Ridge where stable characteristic remanent magnetization (ChRM) directions are easily obtained. Moderately resistant sites are Fort Irwin SW 89-1, -3, -7 and Coyote Canyon 89-5 and 9010. The softest sites are Coyote Canyon 89-6, 90-5 and 90-6, and all sites at Fort Irwin NW. Samples from Gary Owen have soft behavior and are moderately stable; Dacite Dome samples are soft and less stable.

The AFDM behavior suggests that the northeast and north declination directions are primary because these locations have samples that are most resistant. Northwest declination directions are closely associated with soft AFDM behavior which makes them suspect. Although firm remagnetization evidence is lacking, e.g., in the form of consistent direction overprints removed by progressive demagnetization, demagnetization ratio experiments (below) support this hypothesis. Dacite Dome apparently is in the same fault-bounded crustal block as Stone Ridge (Figure 10). Dacite Dome samples show soft demagnetization, poor direction statistics, and northwest declinations. Stone Ridge has hard demagnetization, clear primary magnetization and clearly northeast deflected declinations. Unless there is an unrecognized fault between these locations, Dacite Dome directions are a remagnetization direction acquired after rotation.

Coyote Canyon samples show both styles of demagnetization behavior and both northeast and northwest declinations. Here we sampled three lavas in stratigraphic order: b3, b4, b5 (Figure 4). Hard remanence at $89-5$ and $90-10$ (flow sequence b3 and b4) is southwest deflected with upward inclination and is interpreted as a reversed northeast direction; soft remanence at 90-5 and 6 (b5) is northwest deflected. Both directions are not likely to be primary, as this inter-pretation would require that b4 and b3 were reversely magnetized and that post-b4, they both rotated $>90^{\circ}$ clockwise, then $\mathrm{b} 5$ was deposited, normally magnetized, and then all flows were rotated slightly counterclockwise. This requires a large rotation in a short time period; probably $\ll 1$ m.y. (Table 2). Since the northwest direction is in younger units than the northeast direction, there are at least two other possibilities if some of the rocks were remagnetized: (1) b5 was normally magnetized; post-b5 the location rotated $\sim 90^{\circ}$ counterclockwise; the lower units b4 and b3 were remagnetized in a south (reversed) direction; then the location rotated $\sim 90^{\circ}$ clockwise, or (2) post-b5, all units rotated $-90^{\circ}$ clockwise, then b5 was remagnetized normal and there was no further rotation or slight counterclockwise rotation. Explanation 2 is the least complex. 


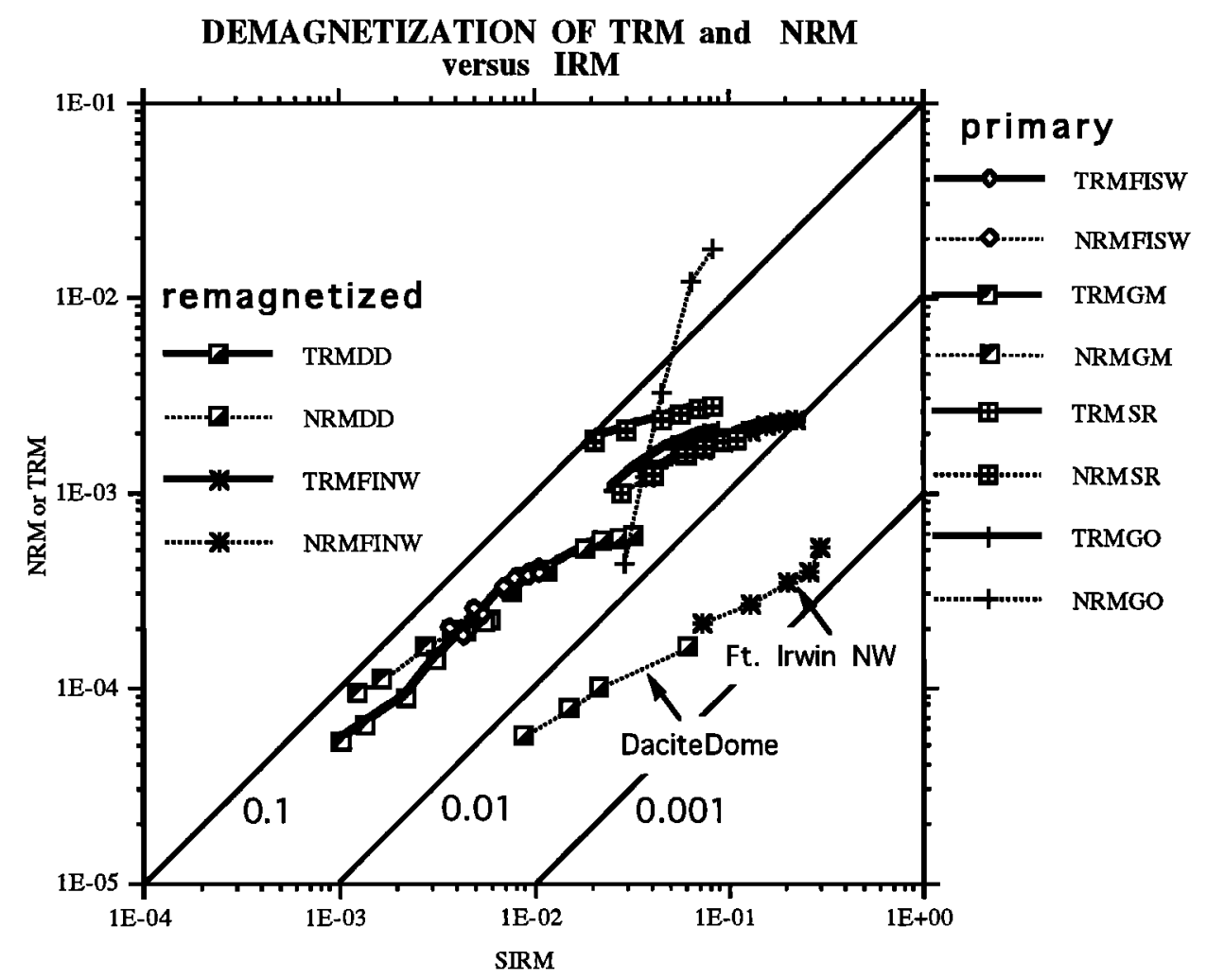

Figure 13. Demagnetization ratios for TRM (heated to $625^{\circ} \mathrm{C}$ then cooled in $0.045 \mathrm{mT}$ field) and NRM versus SIRM of Fort Irwin samples. Demagnetizations were done at 10, 20, 30, 50, and $70 \mathrm{mT}$. Remagnetized and demagnetized samples such as those shown from Dacite Dome and Fort Irwin NW are indicated by significant differences between their TRM/IRM and NRM/IRM demagnetization ratio curves. See text for details. Abbreviations are DD, Dacite Dome; FINW, Northwest ridge; FISW, Southwest ridge; GM, Goldstone Mesa; GO, Gary Owen; SR, Stone Ridge.

The structurally corrected directions of the two normal polarity sites from Coyote Canyon (90-5 and 90-6) are similar to directions for sites at Fort Irwin NW and Dacite Dome (Table 2). Because we suspect that samples from Fort Irwin NW and Dacite Dome are remagnetized (see below), these Coyote Canyon sites are also believed remagnetized. The Coyote Canyon fold test indicates folding here followed rotation and remagnetization.

\section{Rock Magnetism}

Rock magnetic experiments also suggest that the northwest directions are remagnetized, while the north and northeast directions are primary. A comparison of alternating magnetic field demagnetization behavior of NRM to laboratory-induced saturation isothermal remanent magnetism (SIRM) can aid in distinguishing remagnetized paleomagnetic samples from those that have retained their primary remanence [Fuller et al., 1988]. For this method, a $\log _{10} / \log _{10}$ plot of NRM versus SIRM intensity at identical demagnetization levels is employed. For fine grained igneous rocks that still retain much of their primary thermal remanent magnetism (TRM), less altered samples generally display NRM/SIRM ratios of the order of $10^{-2}$ or above, and their NRM/SIRM demagnetization curves have a concave downward shape. This characteristic demagnetization behavior may result from a mixture of abundant fine, and less abundant, coarser magnetic grains [Cisowski et al., 1990, Figure 6]. In contrast, highly altered (naturally demagnetized and remagnetized) samples generally display lower NRM/SIRM ratios in the range of $10^{-3}$, often with linear or concave upward curves [Cisowski, 1992, Figure 8]. As a test of stability we induced some samples with a laboratory TRM and compared the TRM/SIRM demagnetization ratio curves against the NRM/SIRM curves (Figure 13).

Samples from sites displaying north and northeast declinations have different ratio curves than those samples from sites displaying northwest declination (Figure 13). The northeast and north declination samples display concave downward NRM/SIRM demagnetization curves, similar to their TRM/SIRM curves. In contrast, samples from northwest declination sites (Dacite Dome, Fort Irwin NW) have uniformly low NRM/SIRM ratios with demagnetization curve shapes that are strongly dissimilar to their TRM/SIRM curves (Figure 13).

The inference from these observations is that samples from the northeast and north declination sites have retained their primary thermal remanence. The character of the NRM/SIRM curves from Dacite Dome and Fort Irwin NW suggests alteration and remagnetization, so that paleomagnetic evidence for or against tectonic rotation may have been lost. These experimental results suggest that the NRM/SIRM curves may be useful in distinguishing remagnetized sites that appear nonrotated or 
counterclockwise-rotated (Dacite Dome and Fort Irwin NW) from sites retaining primary magnetization that have not been rotated since the time of extrusion and magnetic blocking (Goldstone Mesa and Fort Irwin SW). Further evidence for remagnetization was revealed in electron microscopy and microprobe analysis (Appendix 2).

The northwest direction is consistent among the Fort Irwin NW, Dacite Dome, and Coyote Canyon locations (Table 3). All three locations are in different blocks. We interpret the northwest declination as a nonrotated remagnetized direction. The remagnetization process and timing are unknown but apparently occurred after rotation was complete and, in Coyote Canyon, before folding.

\section{Tectonic Implications of Paleomagnetic Results}

The north directions from Goldstone Mesa and Fort Irwin SW are interpreted as primary and nonrotated; the northeast directions from Stone Ridge, Gary Owen, and two from Coyote Canyon are also interpreted to be primary and to reflect net clockwise vertical axis rotation; the northwest directions from Dacite Dome, Fort Irwin NW, and Coyote Canyon are interpreted as remagnetized and not usable for tectonic analysis (Table 3). The paleomagnetic directions we interpret as primary indicate that $\sim 64^{\circ}$ of net post early Miocene clockwise rotation has occurred (compared to the reference pole of Calderone et al. [1990]). The fact that the Goldstone Mesa sites are nonrotated or possibly slightly clockwise rotated [MacConnell et al., 1994] suggests that the Goldstone Lake fault is a significant tectonic boundary between clockwise rotated (east) and nonrotated (west) crust.

As an independent check of the interpretation of rotated blocks, we observe that the Jurassic Independence Dike Swarm within the elongate fault blocks can be interpreted as rotated relative to the swarm north of the Garlock fault an amount broadly similar to the declination vectors [see also Ron et al., 1995]. Dikes immediately north of the Garlock fault trend $310^{\circ}$ $314^{\circ}$, while in the Granite Mountains in northern Fort Irwin (Figures 2 and 10) they trend $\sim 334^{\circ}$ [Smith, 1962]. This suggests a differential rotation of $20^{\circ}-24^{\circ}$ between these locations. Dikes that have been dated at $148 \pm 14 \mathrm{Ma}$ [Stephens, 1994] and which may be part of the Independence swarm also occur at South Tiefort Mountain (Figure 3). Here they trend $020^{\circ}-030^{\circ}$ suggesting a rotation of $66^{\circ}-80^{\circ}$ relative to north of the Garlock fault. Assuming the northern dikes to be a reference trend, we interpret that the dike swarm outcrops in the northeast Mojave domain have been rotated clockwise $24^{\circ}-80^{\circ}$. This comparison between the declinations and dike trends further suggests that the northeast magnetic declinations are primary and caused by tectonic rotation. Both the paleomagnetic directions and the dike trends also suggest that the northern areas are rotated less than the southern areas within Fort Irwin (Figure 10).

If the dikes in the Tiefort Mountains are indeed part of the Independence swarm, it follows that the rotation affected large crustal blocks that include both Tertiary volcanic and sedimentary cover and pre-Tertiary basement. However, if the Tiefort Mountain dikes are not Independence dikes, the large tectonic rotation inferred from the paleomagnetic data could instead represent either rotation of cover rocks detached from the basement or rotation of local fault blocks adjacent to and within the fault zones that bound the coherent crustal blocks. We see no geologic evidence, however, for detaching of the cover rocks from the basement. The nonconformity beneath Tertiary strata is exposed throughout the Fort Irwin area, and no low-angle faults which might cause differential rotation between Mesozoic basement rocks and Tertiary cover have been identified. The second possibility, of local rotations, is discussed below.

\section{Previous Paleomagnetic Studies}

MacConnell et al. [1994] studied early Miocene basalts from Goldstone Mesa and Pink Canyon (Figures 9 and 10). The AFDM character of their samples also appears to be type 2 (hard) as we found for our Goldstone, Fort Irwin SW, and Stone Ridge sites. They computed clockwise rotations for these sites of $9.6^{\circ} \pm 7.4^{\circ}$ (Goldstone) and $28.4^{\circ} \pm 9.0^{\circ}$ (Pink Canyon). These mean directions have high $k$ (187.5 and 55.1) suggesting secular variation was not averaged. They computed discordance relative to the early Miocene reference pole of Diehl et al., [1988]. The Pink Canyon sites are rotated $\sim 22.6^{\circ}$ clockwise and Goldstone sites are rotated $\sim 3.8^{\circ}$ clockwise with respect to the pole of Calderone et al. [1990].

Ross et al. [1989] found early Miocene clockwise tectonic rotation in a broad swath of the Mojave Desert including the Mojave extensional belt. Rotation in the belt is constrained to be before 18.5 Ma by paleomagnetic studies on the Peach Springs Tuff [Wells and Hillhouse, 1989]. Ross et al. [1989] also studied nine early Miocene flows in the Alvord Mountains (Figure 1). They found a clockwise rotation anomaly of $53.2^{\circ} \pm 9.9^{\circ}$ with respect to the Miocene reference pole of Diehl et al., [1983] ( $\sim 48^{\circ}$ with respect to the Calderone et al. [1990] pole). Ross et al. were uncertain as to the age of the rotation because they believed only early Miocene rocks were sampled. However, the Peach Springs Tuff at Alvord Mountain is rotated $56.1^{\circ} \pm 5.6^{\circ}$ clockwise (R. Wells and J. Hillhouse, written communication, 1994), not statistically different from the Ross et al. result. Further, the andesite flows at Alvord Mountain have been recently dated at $12.8 \mathrm{Ma}$ (K-Ar (A.F. Glazner, written communication, 1995)). Therefore the rotation in the Alvord Mountains can be interpreted as younger than $12.8 \mathrm{Ma}$.

Immediately south of the Manix fault Pluhar et al. [1991] found a rotation of $8^{\circ} \pm 2.7^{\circ}$ clockwise over 2 m.y. for the PlioPleistocene (2.5-0.9 Ma [Nagy and Murray, 1991]) Mojave River Formation in the crustal block between the Cady and Manix faults (Figure 1). MacFadden et al. [1990] sampled the Hector Formation (23-16 Ma) within the northern Cady Mountains (Figure 1) and found a uniform clockwise declination of $18.6^{\circ}\left(I=45.4^{\circ}, \alpha_{95}=5.7^{\circ}\right)$ and no declination change with age within the section. This is interpreted as due to $20.6^{\circ} \pm 7.6^{\circ}$ clockwise rotation post-16 Ma relative to the pole of Irving and Irving, [1982] $\left(\sim 22.4^{\circ}\right.$ clockwise relative to the Calderone et al. [1990] pole). The rotation rate of $\sim 4 \%$ m.y. implied for this crustal block by the Pluhar et al. [1991] study permits $22^{\circ}$ of clockwise rotation over a period of 5 or $6 \mathrm{~m} . y$., suggesting that rotation could have started at the end of Miocene time.

Ross [1995] found large clockwise declination anomalies in the southwest Cady Mountains, south of the Cady fault. He interprets an early Miocene rotation associated with extension in the Mojave at that time and a post-14 Ma clockwise rotation that is attributed to local rotation in a northwest oriented dextral shear zone.

Valentine et al. [1993] found $\sim 15^{\circ} \pm 12^{\circ}$ counterclockwise rotation of middle Miocene sites and no rotation of Pliocene sites 
Table 4. Tectonic Rotations Assigned to Crustal Blocks in the Northeast Mojave Domain

\begin{tabular}{|c|c|c|c|c|}
\hline Fault-Bounded Block & Site Name & Study & Rotation & Age, Ma \\
\hline \multicolumn{5}{|c|}{ East Trending Blocks } \\
\hline $\begin{array}{l}\text { Garlock-Drinkwater } \\
\text { Drinkwater-Fort Irwin }\end{array}$ & $\begin{array}{l}\text { IDS }^{\mathbf{a}} \text { and Gary Owen } \\
\text { none }\end{array}$ & this paper & $24^{\circ}-54^{\circ} \mathrm{CW}$ & $\leq 15.8$ \\
\hline $\begin{array}{l}\text { Nelson Lake/Fort Irwin-Coyote } \\
\text { Canyon/Tiefort Mountain }\end{array}$ & $\begin{array}{l}\text { Stone Ridge, Pink } \\
\text { Canyon }\end{array}$ & this paper, MacConnell et al. [1994] & $23^{\circ}-60^{\circ} \mathrm{CW}$ & $\leq 17$ \\
\hline Tiefort-Bicycle Lake & Coyote Canyon? & this paper & $\leq 90^{\circ} \mathrm{CW} ?$ & $\leq 17.1$ \\
\hline Bicycle Lake-Coyote Lake & IDS $?^{\mathrm{a}}$ & this paper & $66-80^{\circ} \mathrm{CW}$ ? & post-Jurassic \\
\hline Coyote Lake-Manix & Alvord Mountains & $\begin{array}{l}\text { Ross et al. [1989]; J. Hillhouse (written } \\
\text { communication, 1994) }\end{array}$ & $48^{\circ}-56^{\circ} \mathrm{CW}$ & $\leq 12.8 \mathrm{Ma}^{\mathrm{b}}$ \\
\hline Manix-Cady & $\begin{array}{l}\text { Hector Formation } \\
\text { Mojave River Formation }\end{array}$ & $\begin{array}{l}\text { MacFadden et al. }[1990] \\
\text { Pluhar et al. }[1991]\end{array}$ & $\leq 22^{\circ} \mathrm{CW}$ & $<16 \mathrm{Ma}$ \\
\hline \multicolumn{5}{|c|}{ Northwest trending blocks } \\
\hline Goldstone-Blackwater & Goldstone Mesa & $\begin{array}{l}\text { this paper, MacConnell et al. [1994], and } \\
\text { Valentine et al, [1993] }\end{array}$ & $\begin{array}{l}\leq 15^{\circ} \mathrm{CCW} \text { to } 4^{\circ} \\
\mathrm{CW}\end{array}$ & $\leq 13.5 \mathrm{Ma}$ \\
\hline Goldstone-Garlic Springs & Fort Irwin SW & this paper & $7^{\circ} \mathrm{CW}$ & $\leq 17.8 \mathrm{Ma}$ \\
\hline
\end{tabular}

Rotations relative to the pole of Calderone et al. [1990]

${ }^{\mathrm{a}}$ Independence Dike Swarm; see text.

b.F. Glazner (written communication, 1995)

sampled in volcanic rocks between the Blackwater and Goldstone Lake faults (Figure 1). These results are consistent with our findings and those of MacConnell et al. [1994] for the nonrotated sites at Goldstone Mesa. There is a possibility that the Miocene sites to the west of the Goldstone area are counterclockwise rotated about $10^{\circ}$ to $15^{\circ}$ with respect to the Goldstone sites; but this observation is not statistically robust.

From our studies and these prior studies we conclude that crust in northeast Mojave domain bounded by east striking faults has rotated clockwise in post early Miocene time but not coherently (Figure 10 and Table 4). The strain in the region has not been homogeneous as Luyendyk et al., [1980, 1985] and Carter et al., [1987] suggested, but the evidence for widespread clockwise rotation is substantial.

\section{Discussion}

\section{Boundaries of Rotated Domain}

Our paleomagnetic results suggest that the Goldstone Lake fault is the western boundary of the rotated domain. However, because the Fort Irwin NW directions appear to be remagnetized, the southwestern boundary of the rotated domain is not well constrained by the paleomagnetic data. Evidence for possible westward extension of the Bicycle Lake fault between Northwest and Southwest Ridges (Appendix 1 and Figure 9) and the lack of evidence for major faults between the Coyote Canyon fault and Northwest Ridge (Figures 4 and 9) suggest that the rotation boundary lies just north of Southwest Ridge. Farther south, significant differences in the trends of Mesozoic foliations and lineations east and west of the Garlic Spring fault (Figure 3 and Appendix 1) suggest relative clockwise rotation of South Tiefort Mountain and that the boundary of the rotated domain lies along the Garlic Spring fault. The eastern and northern boundaries of the rotated domain remain undefined.

\section{Rotation and Fault Slip}

Field mapping indicates that the east striking faults are sinistral with typically $3-5 \mathrm{~km}$ of offset. Assuming a simple block model wherein 10-km-wide blocks rotate during left slip of $\sim 5 \mathrm{~km}$ along each fault [e.g., Luyendyk et al., 1980; Ron et al., 1984; Nur et al., 1989], clockwise rotation of $\sim 23^{\circ}$ is predicted (Figure 14), or about one-third that inferred from the paleomagnetic measurements. This "mismatch" between slip and rotation also appears to be true for southern parts of the domain (e.g., Manix, Coyote Lake faults) since the magnitude of slip ( $\sim 5$ $\mathrm{km}$ [Meek and Battles, 1990]) and rotation ( 48-56 , Table 4) are similar to those in Fort Irwin. In order to match the observed fault slip with observed rotation, coherent crustal blocks would have to be $<5 \mathrm{~km}$ wide, a value much smaller than that observed.

The discrepancy between slip and rotation suggests that the simple block model is not appropriate and/or that we have either overestimated the rotation or underestimated the slip. There are several possible explanations for this discrepancy: (1) the measured declination does not simply record rotation but also secular variation (see above); (2) the "deficient" slip occurs on other faults, for example, new faults produced when faults rotate into an unfavorable stress orientation [e.g., Ron et al., 1984; Nur et al., 1989]; (3) the "excess" rotation is produced by mechanisms besides slip on parallel faults; and (4) some or all of the faults rotated partly without slipping, either because younger sinistral faults formed or because the entire domain rotated as a rigid body without slip on the faults within it. We favor an explanation where excess rotation is produced by both ductile deformation at the block ends, and by rigid rotation of the Fort Irwin region without slip on the internal faults (explanations 3 and 4).

Most of our paleomagnetic sites were, by necessity, within a few kilometers of the fault zones and at the western ends of the crustal blocks near the domain boundary, whereas slip estimates are typically from the central segments of the faults (Figures 3- 


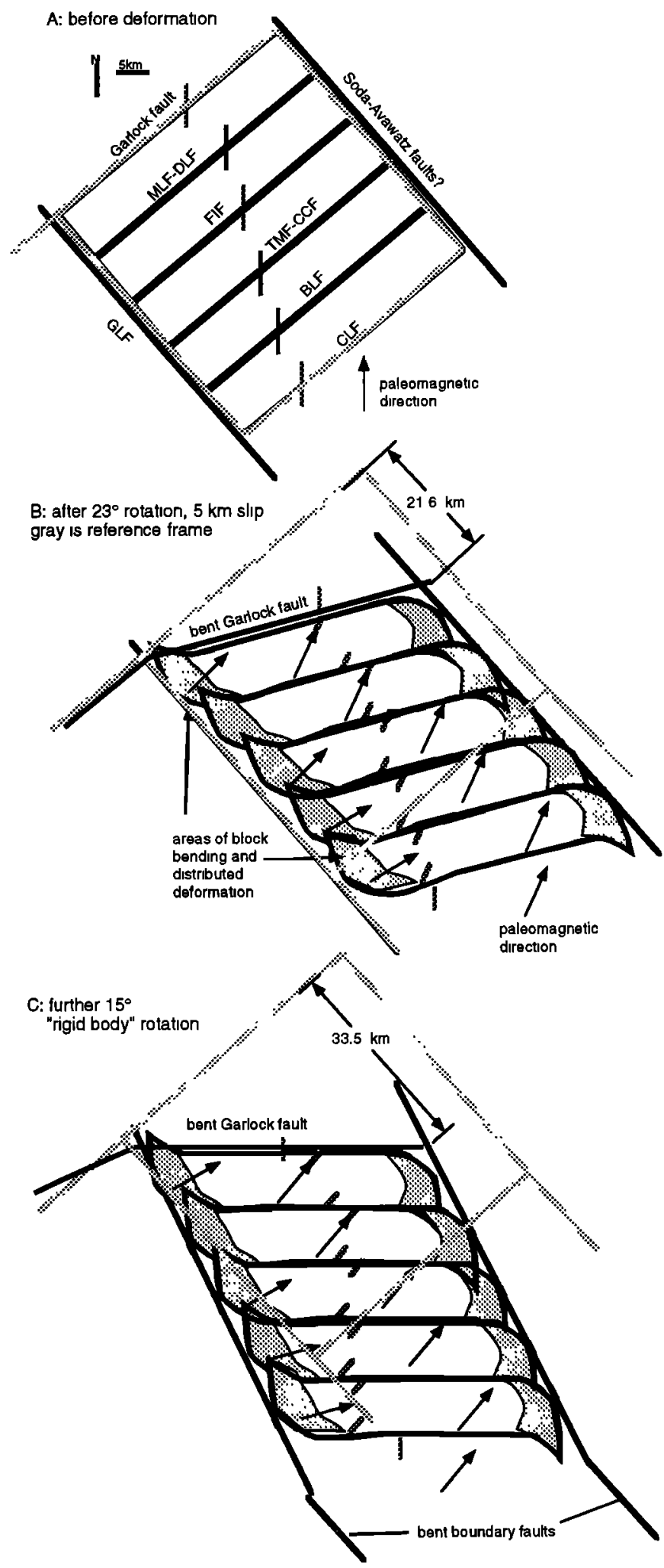

10). However, local rotations adjacent to sinistral fault strands should be counterclockwise, not clockwise, and thus would not explain the large clockwise declination anomalies. The complex intersection of subsidiary northwest and northeast striking faults with the main east striking fault zones produces blocks that could rotate clockwise (and counterclockwise) during north-south shortening (e.g., Figures 3 and 4). Although we do observe evidence for north-south shortening in the form of east-trending folds and reverse faults rotation on the subsidiary faults would require strike-slip on those structures, and is not consistent with the predominant dip-slip observed.

If the "deficient" slip is taken up on a younger, more favorably oriented fault set that formed after blocks rotated 40 or $45^{\circ}$ [e.g., Ron et al., 1984; Nur et al., 1989], we would expect that northwest striking segments of sinistral faults in eastern Fort Irwin are older faults that have rotated. However, all of the studied northwest striking segments have lower dip angles and a larger component of dip-slip than the east striking faults and many, as noted above, are clearly continuously curved from west to northwest strikes (Figures 5, 6, and 8). Throughout the study area, crosscutting relations (e.g., Figures 5 and 6 ) indicate that the two sets are broadly coeval.

It is likely that all of the rotation was not accommodated by fault slip, but instead some was caused by distributed or ductile shearing [e.g., Reches, 1993], particularly at the ends of fault blocks. The observation that the ends of several of the fault blocks are curved (Figure 2) suggests the possibility that the rocks at the ends of the block may rotate independently and more than the main body of the block (Figure 14).

It is also possible that the entire domain may have rotated as a rigid body without slip on internal faults (Figure 14). In such a case the dextral faults bounding the domain would rotate while the internal faults were locked. The paleomagnetic results from Goldstone permit the interpretation that the area bounding the northeast Mojave domain has rotated clockwise $\sim 10^{\circ}-15^{\circ}$ with respect to areas farther west [e.g., Valentine et al., 1993]. Possible dextral faults in the Avawatz Mountains (Figures 1 and 2 and Appendix 1) bounding the eastern edge of the domain strike more northerly $\left(340^{\circ}-345^{\circ}\right)$ than faults to the southeast $\left(\sim 325^{\circ}\right)$, and a similar relationship is seen for the Goldstone lake fault at the western boundary of the rotated domain. A rigid body rotation would add to the rotation amount suggested by fault displacement and account for $23^{\circ}+15^{\circ}=38^{\circ}$ of clockwise rotation. The rigid body rotation could have occurred either before the sinistral faults formed or after they locked. A similar interpretation was proposed for the eastern Transverse Ranges by Richard [1993], who noted that the $41^{\circ}$ clockwise paleomagnetic rotation found by Carter et al. [1987] could not be explained by the observed slip on sinistral east striking faults. He proposed that part of the rotation occurred during sinistral slip on faults within the domain and part occurred during rotation of bounding

Figure 14. Cartoon block model illustrating two mechanisms of rotation to explain discrepancy between fault slip and paleomagnetic data. (a) Before deformation, (b) $5 \mathrm{~km}$ of left slip on faults within domain resulting in $23^{\circ}$ rotation, $22 \mathrm{~km}$ dextral shear. Shaded areas at the ends of blocks are regions where distributed deformation may produce additional clockwise rotation observed in paleomagnetic data. (c) "Rigid-body" rotation of $15^{\circ}$ occuring during dextral slip and rotation along bounding faults. Total dextral shear is $33 \mathrm{~km}$. Rotation may not have occurred in two distinct stages. 
dextral faults without slip on most of the east striking sinistral faults. The evidence for the "rigid" rotation is seen in the clockwise change in trend of the fault bounding the eastern side of the rotated eastern Transverse Ranges domain.

There are some observations consistent with the interpretation of small $\left(\sim 25^{\circ}\right)$, rather than large $\left(60^{\circ}\right)$ crustal block rotations. The clockwise rotation inferred from the trends of the Independence dikes in the Granite Mountains (24-28 ${ }^{\circ}$ and the Gary Owen paleomagnetic data $\left(54^{\circ}\right)$ are different, but they appear to be in the same crustal block (barring differential rotation across the Desert King Spring fault; Figure 7). The paleomagnetic data of MacConnell et al., [1994] from Pink Canyon are consistent with the interpretation of a small clockwise rotation of the crustal block immediately east of the Goldstone Lake fault $\left(28^{\circ} ; 23^{\circ}\right.$ relative to the Calderone et al. [1990] pole). However, the Pink Canyon sites appear to be in the same crustal block as our Stone Ridge sites (Figure 10 and Table 4). The differences between the paleomagnetic results at these four sites can not normally be explained by secular variation. It seems likely that there is an unmapped fault separating the Pink Canyon and Stone Ridge locations. We conclude that at least $25^{\circ}$, and possibly $40^{\circ}$, of clockwise tectonic rotation is consistent with the observed slip on faults within the domain and bending of domain-bounding faults, while the remaining $\sim 25^{\circ}$ is related to local deformation at the ends of the east trending fault blocks.

\section{Kinematic Model for the Northeast Mojave Domain}

A simple two-stage kinematic model is shown in Figure 14. We emphasize that the rotation may not have occurred in two discrete stages; the model is drawn to illustrate the two mechanisms of rotation. In the first stage (Figures 14a and 14b), $23^{\circ}$ of clockwise rotation occurs during $5 \mathrm{~km}$ sinistral slip on each fault. Areas of additional rotation due to bending of the block ends are shaded. In the second stage (Figures $14 \mathrm{~b}$ and $14 \mathrm{c}$ ), an additional $15^{\circ}$ clockwise rotation occurs by slip and rotation of the domain-bounding dextral faults. Although slip on these faults is not well constrained, we interpret the Goldstone Lake fault to have $<5 \mathrm{~km}$ of dextral slip, and thus the rotating blocks are "pinned" at the northwest corner. The model requires northeast-southwest contraction, which is consistent with the mapped structures in eastern Fort Irwin (Figures 2, 6, and 8).

We can use our block model together with the structural and paleomagnetic data to evaluate the amount of dextral shear across the northeast Mojave domain (Figure 14) and its role in the Eastern California Shear Zone. For $23^{\circ}$ of rotation within the domain consistent with the observed slip on the east striking faults, the dextral shear is $\sim 21.6 \mathrm{~km}$. This rotation is consistent with the observed bend of the eastern Garlock fault $\sim 20-30^{\circ}$ clockwise relative to the western Garlock. The total of $\sim 38^{\circ}$ of rotation obtained by adding in the rigid body rotation results in $-33.5 \mathrm{~km}$ of dextral shear. Slip on the Goldstone Lake fault is likely $<5 \mathrm{~km}$; thus the model predicts $\sim 28 \mathrm{~km}$ of dextral slip along the eastern boundary. This value is consistent with the suggestions of Brady, [1984b 1994] and Troxel, [1994] for this boundary, although Davis and Burchfiel, 1[993] suggest $<8 \mathrm{~km}$ slip (see Appendix 1). Dokka and Travis [1990a] and Dokka [1992] proposed $\sim 57 \mathrm{~km}$ of dextral shear in the region from the Blackwater fault to the Avawatz Mountains due to oroclinal bending of the Garlock fault (Figure 1). If their estimate is correct, the shear must be taken up by $\sim 24 \mathrm{~km}$ of dextral shear in the region between the Blackwater fault and the Goldstone Lake fault. The available geologic data suggest that the Blackwater fault, with $\sim 8.5 \mathrm{~km}$ right slip [Dokka, 1983], is the only significant dextral fault in that area. Of the total of $65 \mathrm{~km}$ of dextral shear across the entire width of the Eastern California Shear Zone for the last 10 m.y. [Dokka and Travis, 1990a], approximately half occurs within the Northeast Mojave Domain, and half must occur on dextral faults outside of or bounding the domain.

\section{Conclusions}

The major Cenozoic structures in the northeast Mojave domain are northwest and east striking, strike-slip and oblique-slip faults. East striking faults typically have $\leq 5 \mathrm{~km}$ left slip and a component of reverse movement, suggesting an overall transpressional regime. Field studies indicate a minimum of $\sim 13$ $\mathrm{km}$ cumulative left-lateral shear in the region from south of the Garlock fault to north of the Coyote Lake fault (Figures 1 and 2). Right-lateral slip on northwest striking faults within the domain is less well constrained but appears to be less than $\sim 10 \mathrm{~km}$ total. East striking and northwest striking faults appear to be broadly coeval and affect late Pleistocene strata. Block dimensions established by mapping suggest blocks are (were) $\sim 10 \times 50 \mathrm{~km}$, separated by wide fault zones of densely spaced fault strands. Where the east striking blocks intersect the northwest-trending margins of the domain, uplift due to folding and reverse faulting occurs. The age of initiation of faulting is post middle Miocene.

Up to $60^{\circ}$ of clockwise vertical-axis rotation inferred from paleomagnetic declination anomalies is constrained to have occurred after $12.8 \mathrm{Ma}$. No declination anomaly is shown by sites west of the Goldstone Lake fault and west of the Garlic Spring fault (Figure 10). Several sites with northwesterly declination directions appear to be partly or completely remagnetized and thus cannot be used to infer rotations. The combination of geological and paleomagnetic constraints defines the western boundary of the rotated region as the Goldstone Lake fault and the southwestern boundary as the Garlic Spring fault (Figures 9 and 10). The eastern and northern boundaries remain unconstrained.

The mismatch between fault slips determined from geologic data and rotations inferred from paleomagnetic declination anomalies is due to the three-dimensional nature of the deformation in the domain and the apparent nonrigidity of the fault blocks. Simple plane strain rotating block models are not appropriate to predict fault slip from vertical-axis rotations. However, it is also possible that some of the observed clockwise declination anomaly is due to a regional-scale rigid body rotation of the blocks within the Northeast Mojave Domain.

Acknowledgments. We greatly appreciate the cooperation of the staff at the Goldstone Deep Space Communications Center and the Fort Irwin National Trainıng Center including Walt Cassidy and Rene Quinones. Field assistants include Jeff Johnson, Jim Carter, Roger Haston, Mike Hettinga, Hillary Dervin, Marty Parris, Tim Ross, and Chris Travis. Marty Parris and Bob Dunn assisted with lab work. Ar/Ar work was done in collaboration with Phil Gans and Andy Calvert at UCSB. Dave Miller and Jim Yount of the USGS are thanked for financial and logistical support, as well as beneficial discussions in the field, and John Nakata and Allen Glazner provided additional K-Ar data. G.I. Smith provided aerial photos, reconnasssance maps, and helpful advice. This research was supported by National Science Foundation grants EAR 9105047 (Luyendyk) and EAR 9104915 (Schermer). Contribution 0235-61TC of the Institute for Crustal Studies. 


\section{References}

Atwater, T., Implications of plate tectonics for the Cenozoic tectonic evolution of western North America, Geol. Soc. Am. Bull., 81, 3513-3536, 1970.

Atwater, T., Plate tectonic history of the northeast Pacific and western North America, in The Geology of North America, vol. N, The Eastern Pacific Ocean and Hawaii, edited by E. L. Winterer et al., pp. 21-72, Geol. Soc. Am., Boulder, Colo., 1989.

Bartley, J. M., A. F. Glazner, and E. R. Schermer, North-south contraction of the Mojave block and strike-slip tectonics in southern California, Science, 248, 13981401, 1990.

Brady, R. H., Cenozoic geology of the northem Avawatz Mountains in relation to the intersection of the Garlock and Death Valley fault zones, San Bernardino County, California, Ph.D. Thesis, 292 pp., Univ. Calif., Davis, 1984a.

Brady, R. H., Neogene stratigraphy of the Avawatz Mountains between the Garlock and Death Valley fault zones, southern Death Valley, California: Implications as to the Late Cenozoic tectonics, Sediment. Geol., 38, 127-157, 1984b.

Brady, R. H., The Miocene Military Canyon Formation: Depocenter destruction and constraints on lateral faulting, southern Death Valley, California, Geol. Soc. Am Abstr. Programs, 26, 41, 1994.

Brady, R. H., and R. K. Dokka, The eastern Mojave Shear Zone: A major Tertiary tectonic boundary in the southwestern Cordillera, Geol. Soc. Am. Abstr. Programs, 21, 59, 1989.

Brady, R. H., and K. L. Verosub, Intersecting wrench faults, northeastern Mojave terrane, and symmetrical terminations of the Garlock fault, southern California, Geol. Soc. Am. Abstr. Programs, 16, 453, 1984.

Butler, R. F., Paleomagnetism: Magnetic Domains to Geologic Terranes, 319 pp., Blackwell Sci., Cambridge, Mass., 1992.

Byers, F. M., Jr., Geology of the Alvord Mountain Quadrangle, San Bernardino County, California, U.S. Geol. Surv. Bull., 1089-A, 71 pp., 1960.

Calderone, G. J., R. F. Butler, and G. D. Acton, Paleomagnetism of Middle Miocene volcanic rocks in the Mojave-Sonora Desert region of western Arizona and southeastern California, J. Geophys. Res., 95, 625-648, 1990.

Carter, J. N., B. P. Luyendyk, and R. R. Terres, Neogene clockwise rotation of the eastern Transverse Ranges, California, suggested by paleomagnetic vectors, Geol. Soc. Am. Bull., 98, 199-206, 1987.

Cisowski, S. M., NRM/IRM measurements on sedimentary and igneous rocks from Leg 126, Izu-Bonin arc, Proc. Ocean Drill. Program Sci. Results, 126, 333-340, 1992
Cisowski, S. M., J. R. Dunn, M. D. Fuller, and P. J. Wasilewski, NRM:IRM(s) demagnetization plots of intrusive rocks and the origin of their NRM, Tectonophysics, 184, 35-54, 1990.

Davis, G. A., and B. C. Burchfiel, Tectonic problems revisited: The eastern terminus of the Miocene Garlock fault and the amount of slip on the southern Death Valley fault zone, Geol. Soc. Am. Abstr. Programs, 25, 28, 1993.

Demarest, H. H. J., Error analysis for the determination of tectonic rotation from paleomagnetic data, J. Geophys. Res., 88, 4321-4328, 1983.

Dibblee, T. W., Jr., Evidence of strike-slip faulting along northwest-trending faults in the Mojave Desert, U.S. Geol. Surv. Prof. Pap., 424-B, B197-199, 1961.

Dibblee, T. W., Jr., Areal geology of the western Mojave Desert, California, U.S. Geol. Surv. Prof. Pap., 522, 153, 1967.

Diehl, J. F., M. E. Beck Jr., S. Beske-Diehl, D. Jacobson, and B. C. Hearn, Paleomagnetism of the late Cretaceous-early Tertiary north central Montana alkalic province, $J$. Geophys. Res., 88, 10,593-10,609, 1983.

Diehl, J. F., K. M. McClannahan, and T, J Bornhorst, Paleomagnetic results from the Mogollon-Datil volcanic field, southwestern New Mexico, and a refined Mid-Tertiary reference pole for North America, $J$. Geophys. Res., 93, 4869-4879, 1988.

Dokka, R. K., Displacements on late Cenozoic strike-slip faults of the central Mojave Desert, California, Geology, 11, 305-308, 1983.

Dokka, R. K., The Mojave Extensional Belt of southern California, Tectonics, 8, 363-390, 1989.

Dokka, R., The eastern California shear zone and its role in the creation of young extensional zones in the Mojave Desert region, in Structure, Tectonics, and Mineralization of the Walker Lane, edited by S. D. Craig, pp. 161-186, Geol. Soc. Nev., Reno, 1992.

Dokka, R. K., and C. J. Travis, Late Cenozoic strike-slip faulting in the Mojave Desert, California, Tectonics, 9, 311-340, 1990a.

Dokka, R. K., and C. J. Travis, Role of the eastern California shear zone in accommodating Pacific-North American plate motion, Geophys. Res. Lett., 17, 1323 1326, 1990b.

Dokka, R. K., M. McCurry, M. O. Woodburne, E. G. Frost, and D. Okaya, Field guide to the Cenozoic crustal structure of the Mojave Desert, in This Extended Land, Geological Journeys in the Southern Basin and Range, Spec. Pub. 2, edited by D. L. Weide and M. L. Faber, pp. 21-44, Dept. Geosci., Univ. Nev. Las Vegas, 1988.

Fuller, M., S. M. Cisowski, M. Hart, R. Haston, and E. Schmidtke, NRM:IRM(s) demagnetization plots: An aid to the interpretation of natural remanent magnetization, Geophys. Res. Lett., 15, 518$521,1988$.

Garfunkel, Z., Model for the late Cenozoic tectonic history of the Mojave Desert and its relation to adjacent areas, Geol. Soc. Am. Bull., 85, 1931-1944, 1974.

Glazner, A. F., and J. M. Bartley, Eruption of alkali basalts during crustal shortening in southern California, Tectonics, 13, 493-498, 1994.

Glazner, A. F., J. M. Bartley, and J. D. Walker, Geology of the Waterman Hills detachment fault, central Mojave Desert, California, in This Extended Land, Geological Journeys in the Southern Basin and Range, Spec. Pub. 2, edited by D. L. Weide and M. L. Faber, pp. 225-237, Dept. Geosci., Univ. Nev. Las Vegas, 1988.

Glazner, A. F., J. M. Bartley, and J. D. Walker, Magnitude and significance of Miocene crustal extension in the central Mojave Desert, California, Geology, 17, 50-53, 1989.

Irving, E, and G. A. Irving, Apparent polar wander paths, Carboniferous through Cenozoic and the assembly of Gondwana, Geophys. Surv., 5, 141-188, 1982.

Jennings, C. W., Preliminary fault activity map of California, Calif. Dept. of Conserv., Div. of Mines and Geol., Sacramento, 1992.

Jennings, C. W., J. L. Bumett, and B Troxel, Geologic map of California, Olaf P. Jenkins edition, Trona sheet, Calif. Div. of Mines and Geol., Sacramento, 1962.

Keith, L., J. S. Miller, A. F. Glazner, and E. R. Schermer, Geochemistry of Miocene volcanism on Fort Irwin, northern Mojave Desert, California, Geol. Soc. Am. Abstr. Programs, 26, 62-63, 1994.

Lindvall, S. C., and T. K. Rockwell, Recurrent Holocene faulting along the Johnson Valley portion of the 1992 Landers earthquake surface rupture, Geol. Soc. Am. Abstr. Programs, 25, 70, 1993.

Luyendyk, B. P., A model for Neogene crustal rotations, transtension and transpression in Southern California, Geol. Soc. Am. Bull., 103, 1528-1536, 1991.

Luyendyk, B. P., M. J. Kamerling, and R. Terres, Geometric model for Neogene crustal rotations in southern California, Geol. Soc. Am. Bull., 91, 211-217, 1980.

Luyendyk, B. P., M. J. Kamerling, R. Terres, and J. S. Hornafius, Simple shear of southern California during the Neogene, $J$. Geophys. Res., 90, 12,454-12,466, 1985.

MacConnell, D. F., C. McCabe, R. K. Dokka, and $\mathrm{M}$. Chu, Paleomagnetic and structural evidence for localized tectonic rotation associated with fault drag in the northeastern Mojave Desert: Implications for the late Cenozoic tectonic evolution of eastern 
California, Earth Planet. Sct. Lett., 126, 207216, 1994.

MacFadden, B. J., M. O. Woodburne, and N. D. Opdyke, Paleomagnetism and Neogene clockwise rotation of the northern Cady Mountains, Mojave Desert of southern California, J. Geophys. Res., 95, 4597-4608, 1990.

Meek, J., and D. A. Battles, Evidence for approximately $5.2 \mathrm{~km}$ of left-lateral displacement on the Manix fault, central Mojave Desert, California, Geol. Soc. Am. Abstr. Programs, 22, 68, 1990.

Miller, D. M., J. C. Yount, E. R. Schermer, and T. J. Felger, Preliminary assessment of the recency of faulting at southwestern Fort Irwin, north-central Mojave Desert, California, Publ. 94-1, pp. 41-52, San Bernardino County Mus. Assoc., San Bernardino, Calif., 1994.

Miller, E. L., and J. F. Sutter, Structural geology and ${ }^{40} \mathrm{Ar}-{ }^{39} \mathrm{Ar}$ geochronology of the Goldstone-Lane Mountain area, Mojave Desert, California, Geol. Soc. Am. Bull., 93, 1191-1207, 1982.

Nagy, E. A., and B. C. Murray, Stratigraphy and intra-basin correlation of the Mojave River Formation, central Mojave desert, California, San Bernardino County Mus. Assoc Q., 38, 5-30, 1991.

Nilsen, T. H., and R. H. Chapman, Bouguer gravity map of California, Trona sheet, Calif. Div. of Mines and Geol., Sacramento, 1971.

Nur, A., H. Ron, and O. Scotti, Mechanics of distributed fault and block rotation, in Paleomagnetic Rotations and Continental Deformation, edited by C. Kissel and C. Laj, pp. 209-228, Kluwer Acad, Norwell, Mass., 1989.

Pluhar, C. J., J. L. Kirschvink, and R. W Adams, Magnetostratigraphy and clockwise rotation of the Plio-Pleistocene Mojave River formation, central Mojave desert, California, San Bernardino County Mus. Assoc. Q., 38, 31-42, 1991.

Reches, Z., How rigid are "rigid" crustal blocks?, EOs Trans. AGU, 74 (43), Fall Meet. Suppl., 207, 1993.

Richard, S. M., Palinspastic reconstruction of southeastern California and southwestern Arizona for the Middle Miocene, Tectonics, 12, 830-854, 1993.

Rockwell, T. K., S. Lindvall, G. W. Berger, and D. J. Huntley, Timing of late Quaternary earthquakes along the southern portion of the Landers earthquake $\left(1992 ; M_{w} 7.4\right)$ rupture based on luminescence dating: Is this a new fault or business as usual?, Geol Soc. Am. Abstr. Programs, 27, A-376, 1995.

Ron, H., R. Freund, Z. Garfunkel, and A. Nur, Block rotation by strike-slip faultung: Structural and paleomagnetic evidence, $J$. Geophys. Res., 89, 6256-6270, 1984.

Ron, H., A. Nur, and M. O. McWilliams, Mojave block tectonics: The Independence dike swarm as marker for vertical axis material rotations, Eos Trans. AGU, 76 (46), Fall Meet. Supp., F556, 1995.

Ross, T. M., North-south-directed extension, timing of extension, and vertical axis rotation of the southwest Cady Mountains, Mojave Desert, California, Geol. Soc. Am. Bull., 107, 793-811, 1995.

Ross, T. M., B. P. Luyendyk, and R. B. Haston, Paleomagnetic evidence for Neogene tectonic rotations in the Central Mojave Desert, California, Geology, 17, 470-473, 1989.

Sabin, A. E., F. C. Monastero, A. M. Katzenstein, and L. W. Snee, Geology, geophysics and age of a Late Miocene, intermediate-silicic, collapsed stratovolcano complex in the northern Mojave Desert, CA, Geol. Soc. Am. Abstr. Programs, 25, 140, 1993.

Sabin, A. E., F. C. Monastero, and A. M. Katzenstein, Middle to Late Miocene age stratovolcano on the South Ranges, Naval Air Weapons Station, San Bernardino County, California, in Geological Investigations of an Active Margin, Guidebook, edited by S. F. McGill and T. M. Ross, pp. 293-301, Geol. Soc. of Am. Cordilleran Sect., San Bernardino, Calıf., 1994.

Saltus, R. W., and R. C. Jachens, Gravity and basin-depth maps of the Basin and Range province, western United States, U.S. Geol. Surv. Geophys. Invest. Map, GP-1012, 1995

Sauber, J., W. Thatcher, and S. Solomon, Geodetic measurement of deformation in the central Mojave Desert, California, $J$. Geophys. Res., 91, 12,683-12,694, 1986.

Sauber, J., W. Thatcher, S. Solomon, and M. Lisowski, Geodetic slip rate for the eastern California shear zone and the recurrence time of Mojave desert earthquakes, Nature, 367, 264-266, 1994.

Savage, J. C., M. Lisowski, and W. H. Prescott, An apparent shear zone trending northnorthwest across the Mojave desert into Owens Valley, eastern California, Geophys. Res. Lett., 17, 2113-2116, 1990.

Schermer, E. R., Age and tectonic setting of Miocene volcanism in the northern Mojave Desert, Geol. Soc. Am. Abstr. Programs, 26, 250, 1994.

Schermer, E. R., K. A. Stephens, J D. Walker, C. J. Busby, and J. M. Mattınson, Jurassic and Cretaceous magmatism and tectonism in the Mojave Desert, CA, Geol. Soc Am. Abstr. Programs, 26, 89, 1994.

Smith, G. I., Large lateral displacement on the Garlock Fault, California, as measured from offset dike swarms, Am. Assoc. Pet. Geol. Bull., 46, 85-104, 1962.

Sobieraj, J., Sedimentology and tectonics of Tertiary fan deposits, Fort Irwin, northern Mojave Desert, M.S. Thesis, 111 pp., West. Wash. Univ., Bellingham, 1994.

Sobieraj, J. A., and E. R. Schermer, Sedimentology and tectonics of displaced alluvial fans on Fort Irwin, NE Mojave
Desert, California, Geol. Soc. Am. Abstr. Programs, 26, 94, 1994.

Spencer, J. E., Geologic map of southern Avawatz Mountains, northeastern Mojave Desert Region, San Bernardino County, California, U.S. Geol. Surv. Misc. Field Stud. Map, MF-2117, 1990a.

Spencer, J. E., Late Cenozoic extensional and compressional tectonics in the southern and western Avawatz Mountains, southeastern California, in Basin and Range Extensional Tectonics near the Lattude of Las Vegas, Nevada, edited by B. P. Wernicke, Mem. Geol. Soc. Am.,176, pp. 317-333, 1990b.

Stephens, K. A., Mesozoic tectonics of the Tiefort Mountains, NE Mojave Desert, California, M.S. Thesis, 130 pp., West Wash. Univ., Bellingham, 1994.

Stephens, K. A., E. R. Schermer, and J. D. Walker, Mesozoic intra-arc deformation in the northeast Mojave Desert, Geol. Soc. Am. Abstr. Programs, 25, 150, 1993.

Troxel, B. W., Right-lateral offset of ca $28 \mathrm{~km}$ along a strand of the southem Death Valley fault zone, Califomia, Geol. Soc. Am. Abstr. Programs, 26, 99, 1994.

Valentine, M. J., L. L. Brown, and M. P. Golombek, Cenozoic crustal rotations in the Mojave Desert from paleomagnetic studies around Barstow, California, Tectonics, 12 , 666-677, 1993.

Walker, J. D., J M. Bartley, and A. F. Glazner, Large-magnitude Miocene extension in the central Mojave Desert ${ }^{-}$Implications for Paleozoic to Tertiary paleogeography and tectonics, J. Geophys. Res., 95, 557-569, 1990.

Wallace, R. E., Patterns and timing of late Quaternary faulting in the Great Basin province and relation to some regional tectonic features, J. Geophys. Res., 89, $5763-$ $5769,1984$.

Wells, R. E., and J W. Hillhouse, Paleomagnetism and tectonic rotation of the lower Miocene Peach Springs Tuff: Colorado Plateau, Arizona, to Barstow, California, Geol. Soc. Am Bull, 101, 846863, 1989.

Yount, J. C., E. R. Schermer, T. J. Felger, D. M. Miller, and K. A. Stephens, Preliminary geologic map of Fort Irwin basin, northcentral Mojave Desert, California, U.S. Geol. Surv. Open-File Rep., 94-173, 1994.

S. Cisowski and B P. Luyendyk, Institute for Crustal Studies, University of California, Santa Barbara, CA 93106.

(c-mail: cisowski@magic.geol.ucsb.edu; luyendyk@quake.crustal.ucsb.edu)

E. R Schermer, Geology Department, MS 9080, Western Washington University, Bellingham, WA 98225.

(e-mail: schermer@henson.cc.wwu.edu)

(Received July 26, 1995; revised December 27, 1995; accepted January 4, 1996.) 